\title{
Review \\ Cellular Plasticity: A Route to Senescence Exit and Tumorigenesis
}

\author{
Hadrien De Blander 1,2,*, Anne-Pierre Morel 1,2,3 ${ }^{1}$, Aruni P. Senaratne ${ }^{4}$, Maria Ouzounova ${ }^{1,2,3,5}$ \\ and Alain Puisieux $1,2,3,5, *$
}

1 Equipe Labellisée Ligue Contre le Cancer "EMT and Cancer Cell Plasticity", CNRS 5286, INSERM 1052, Centre Léon Bérard, Cancer Research Center of Lyon, Université Claude Bernard Lyon 1, 69008 Lyon, France; anne-pierre.morel@lyon.unicancer.fr (A.-P.M.); maria.ouzounova@lyon.unicancer.fr (M.O.)

2 LabEx DEVweCAN, Université de Lyon, 69008 Lyon, France

3 Institut Curie "EMT and Cancer Cell Plasticity", Consortium Centre Léon Bérard, 69008 Lyon, France

4 UMR3664-Nuclear Dynamics, Development, Biology, Cancer, Genetics and Epigenetics, Institut Curie, PSL Research University, 75005 Paris, France; aruni.senaratne@curie.fr

5 CNRS UMR3666, Inserm U1143, Cellular and Chemical Biology, Institut Curie, PSL Research University, 75005 Paris, France

* Correspondence: hadrien.deblander@kuleuven.be (H.D.B.); alain.puisieux@curie.fr (A.P.)

check for updates

Citation: De Blander, H.; Morel, A.-P.; Senaratne, A.P.; Ouzounova, M.; Puisieux, A. Cellular Plasticity: A Route to Senescence Exit and Tumorigenesis. Cancers 2021, 13, 4561. https://doi.org/10.3390/cancers 13184561

Academic Editor: Steven M. Frisch

Received: 17 August 2021

Accepted: 8 September 2021

Published: 11 September 2021

Publisher's Note: MDPI stays neutral with regard to jurisdictional claims in published maps and institutional affiliations.

Copyright: (C) 2021 by the authors. Licensee MDPI, Basel, Switzerland. This article is an open access article distributed under the terms and conditions of the Creative Commons Attribution (CC BY) license (https:/ / creativecommons.org/licenses/by/ $4.0 /)$.
Simple Summary: Senescence is a form of cell cycle arrest induced by stresses such as DNA damage and oncogenes and therefore constitutes a crucial barrier against cancer. Nevertheless, senescent cells can escape or bypass this tumor suppressor mechanism and evolve towards an altered, precancerous genotype. Furthermore, accumulated senescent cells that are not cleared by the immune system secrete pro-inflammatory factors, promoting malignant phenotypes. This pro-tumor activity of senescence is associated with genetic reprogramming and the acquisition of cellular plasticity. In this review, we aim to unravel the interconnection between senescence, senescence-associated pro-inflammatory cytokines and the induction of cellular plasticity, which enables the adaptability of tumor cells at different stages of carcinogenesis.

Abstract: Senescence is a dynamic, multistep program that results in permanent cell cycle arrest and is triggered by developmental or environmental, oncogenic or therapy-induced stress signals. Senescence is considered as a tumor suppressor mechanism that prevents the risk of neoplastic transformation by restricting the proliferation of damaged cells. Cells undergoing senescence sustain important morphological changes, chromatin remodeling and metabolic reprogramming, and secrete pro-inflammatory factors termed senescence-associated secretory phenotype (SASP). SASP activation is required for the clearance of senescent cells by innate immunity. Therefore, escape from senescence and the associated immune editing would be a prerequisite for tumor initiation and progression as well as therapeutic resistance. One of the possible mechanisms for overcoming senescence could be the acquisition of cellular plasticity resulting from the accumulation of genomic alterations and genetic and epigenetic reprogramming. The modified composition of the SASP produced by these reprogrammed cancer cells would create a permissive environment, allowing their immune evasion. Additionally, the SASP produced by cancer cells could enhance the cellular plasticity of neighboring cells, thus hindering their recognition by the immune system. Here, we propose a comprehensive review of the literature, highlighting the role of cellular plasticity in the pro-tumoral activity of senescence in normal cells and in the cancer context.

Keywords: cellular plasticity; senescence; reprogramming; immune evasion; epithelial-mesenchymal transition

\section{Introduction}

Senescence is characterized by permanent cell cycle arrest and is generally considered irreversible. It is triggered by developmental signals or various endogenous and exogenous 
stressors, including telomere shortening, physically or chemically induced DNA damage, oncogene activation, exposure to reactive oxygen species (ROS), and therapeutic treatments like chemo- or radiotherapies [1]. The cessation of cell proliferation via senescence involves a number of phenotypic and functional changes to cells. These include morphological alterations, chromatin remodeling, metabolic reprogramming and secretion of a complex mix of proinflammatory factors termed the senescence-associated secretory phenotype (SASP) [2]. Depending on the type of senescence-inducing trigger and the type of target cell, the collective changes accompanying individual senescence responses are highly diverse. For example, differences have been observed in the stop phase of the cell cycle as well as in the types of regulatory circuits involved during senescence of fibroblasts vs. senescence of epithelial cells, keratinocytes or melanocytes [3,4].

The senescence pathway has critical implications in normal physiological processes like embryonic development, tissue regeneration and wound healing [5-8]. For example, fibroblast cells, which play major roles in maintaining tissue structure, will senesce at a wound site to release SASP factors that permit their differentiation into myofibroblasts, the main repair cells that restore tissue integrity and facilitate wound closure following injury $[5,9,10]$. The senescence program is thus generally beneficial, involving a positive, transient role for senescent cells. However, if these cells persist, then senescence plays a causal and deleterious role in certain pathologies. For instance, the buildup of senescent fibroblasts in tissues and organs is central to age-related disruption of tissue structure and function and conditions like fibrosis [11-13]. Accumulation of senescent cells is also implicated in cancer [7,14-16]. Indeed, two outcomes as disparate as wound healing vs. tumorigenesis, consolidated by one biological pathway, supports the theory that a tumor is a 'wound that does not heal' [17-19].

Although the vast majority of studies on senescence have been carried out on fibroblast models, another cell type that is highly relevant to understanding the deteriorative effects of the senescence program is the epithelial cell, another key contributor to tissue and organ structure and function. Epithelial cells can undergo cellular reprogramming through epithelial to mesenchymal transition (EMT), a process that imparts features of stemness and plasticity to cells [20-22]. While EMT, like senescence, is physiologically involved in development and wound repair [23,24], dysfunctional EMT associated with the senescence program is a major contributor to certain pathologies. For example, epithelial cells morphologically close to myofibroblasts can undergo EMT, leading to epithelial remodeling and massive extracellular matrix (ECM) deposition, ECM stiffness and the thickening of pulmonary tissue resulting in fibrosis $[25,26]$. These cells, reprogrammed during chronic inflammation, are a key component of the senescence response, and their aberrant accumulation further catalyzes the generation of damaged fibrotic tissue [25-29].

The interplay between cellular reprogramming and senescence has drastic implications for tumor development and progression [30-35]. In this context, malignant cells can undergo EMT-mediated reprogramming to acquire features of plasticity and stemness that help these cells overcome the tumor suppressor action of senescence and continue proliferating [36-42]. Specifically, cells can defeat the senescence barrier either through a mechanism of "escape" or a mechanism of "bypass". The molecular context of these two mechanisms will be described in detail in the next sections. Senescence is thus observed to have opposite effects in the circumstances of cancer; first, in preventing the proliferation risk of neoplastic cells via cell cycle arrest; yet, second, in creating a window of opportunity for cancer cells to fight senescence and progress along the path to more aggressive tumors. In this review, we elucidate this double-edged sword in cancer biology by deciphering how the interplay between senescence and cellular plasticity has an impact from tumor initiation up to therapeutic resistance.

\section{Overcoming Senescence via Escape Instigates Neoplasticity and Genomic Instability in Pre-Tumoral Cells}

Senescence is considered an "evolutionary cul-de-sac" for cells, as it generally implies the inability to resume cell proliferation [36,43-45]. However, some cells like epithelial cells 
are capable of spontaneously reverting to a proliferative state following cell cycle arrest after encountering a stress signal, a process known as "senescence escape". Senescence escape is facilitated by altering the activity of chromatin regulators, metabolic pathways or extracellular $\mathrm{pH}[43,46,47]$. The senescence program in epithelial cells involves a period known as "stasis", or telomere-independent senescence. Here, a decrease in poly (ADP) ribose-polymerase 1 (PARP1) expression compromises the repair of single strand breaks (SSBs) in senescent epithelial cells, which induces the persistence of single strand break repair (SSBR) foci $[4,48]$. In turn, a signaling cascade is engaged, leading to p38MAPK/p16mediated cell cycle arrest (stasis). These events are associated with some characteristic features: enlarged and flattened morphology, an inflammatory secretome, and senescenceassociated $\beta$-galactosidase-positive, polynucleated cells [48-53].

It has been estimated that about one in $10^{4}$ epithelial cells spontaneously escapes from stasis and reenters the cell cycle to give rise to new clones $[50,54,55]$. This is associated with certain epigenetic changes that distinguish "escaped" epithelial cells from the rest, including hypermethylation of p16 promoter DNA, resulting in decreased CDKN2A expression [56-60]. Notably, the reported epigenetic modifications have been correlated with methylation signatures found in hyperplasia, which is often the initial stage of cancer development [57].

Escape from stasis in epithelial cells is found to accompany the acquisition of some hallmark features of cancer cells. Notably, cell plasticity is induced through EMT, as evident in the expression of EMT transcription factors (EMT-TFs) [48]. Furthermore, epithelial and mesenchymal markers are found to be lost and gained, respectively, which is known to promote invasive and metastatic properties of cells $[48,61,62]$. Although the role of EMT in stasis escape has not yet been elucidated, the latter observation suggests that plasticity features may help epithelial cells to overcome oncosuppressive barriers. Of note, given that PARP1 downregulation promotes stasis, EMT has recently been linked to PARP1 decrease as a means of escaping senescence [63-65]. In the context of deciphering this connection, it will be interesting to impede EMT or PARP-1 action in epithelial cells and investigate its impact on the stasis escape process as a whole.

While stasis is essentially a characteristic of epithelial cells, three additional modes of senescence are described in other cell types: (i) replicative senescence (RS) or telomeredependent senescence, which has been historically characterized in fibroblasts and is caused by telomere shortening; (ii) oncogene-induced senescence (OIS), following the activation of an oncogene such as RAS; and (iii) therapy-induced senescence (TIS), following cancer treatments like chemo- and radiotherapy $[16,44,66]$. These senescence types are activated by the $\mathrm{p} 53 / \mathrm{p} 21^{\mathrm{WAF} 1}$ tumor suppressor pathway and share the common feature of being induced by genotoxic stresses. Consequently, RS, OIS and TIS are associated with endoreplication, polyploidy-induced DNA damage and genomic instability, as well as extensive epigenetic reprogramming $[55,56,59,67-73]$. However, mechanisms of escape have been described that enable these damaged cells to re-enter the cell cycle, including for senescent fibroblasts, which are known to be mostly incapable of resuming cell proliferation owing to the high stability of RS-induced DNA damage [4]. These mechanisms target polyploid cells for depolyploidization and budding.

Polyploid cells are generally considered to be terminally differentiated because they can no longer divide. However, genomic instability in polyploid cells might provide a route to aneuploidy, which is long thought to play a major role in p53 status-independent tumor initiation [73-79]. Here, multinucleate giant polyploid cells can restore their proliferative capacity by undergoing an atypical type of cell division known as "neosis", initially identified during tumor progression as well as in normal cells [49,80-83]. Neosis results in daughter cells with reduced cell ploidy (depolyploidization) and extended mitotic life span [80], thus being at the origin of senescence escape [77,80,82,84-87]. Like epithelial cells that escape stasis, stem-like properties following depolyploidization have been reported in fibroblasts that have escaped from RS or in melanocytes that have escaped from OIS, allowing the acquisition of anoikis resistance and tumorigenic capacities [77,88]. Furthermore, 
in fibroblasts undergoing RS, telomere-driven chromosome instability displays massive changes in expression of microRNAs (miR), including the miR-200-family. miR-200 is a well-known negative regulator of EMT-TFs that confers plasticity-related phenotypic traits to immortalized pre-tumoral cells [68].

Senescence escape can thus be facilitated in major cell types by the dedifferentiation associated with large-scale cellular reprogramming and polyploidy. Reminiscent of a blastomere-like process of dedifferentiation in somatic cells for tumor initiation, senescenceescaped cells too can evolve towards novel tumorigenic states which, in the case of polyploidy, can accompany modified genomic profiles [86,89,90].

\section{Overcoming Senescence via Bypass Preserves a Stable Tumor Genome}

At times, cells can continue to proliferate even in the presence of stressors that would likely lead to cell cycle arrest. This process, known as senescence bypass, differs from senescence escape in that a senescent stage is entirely absent in cells. Notably, the propensity of a cell to bypass senescence appears to depend on its differentiation state. More specifically, in contrast to progenitor cells that are more committed to differentiation, stem cells of the young adult do not senesce [91-93]. This correlation between the degree of cellular differentiation and the likelihood of bypassing senescence has significant implications in tumor development [41].

As described in the concept of cellular pliancy, each stage of differentiation within a specific cell lineage is associated with a unique susceptibility to malignant transformation when subjected to a specific oncogenic insult [41]. In this context, differentiated cells are typically vulnerable to OIS, whereas stem cells can overcome OIS and DNA damage. This resistance is conferred to stem cells through the expression of EMT-TFs that promote cell plasticity while inhibiting the $\mathrm{p} 16 / \mathrm{Rb}$ pathway to cell cycle arrest $[34,93]$. Specifically, TWIST proteins have been shown to down-regulate the expression of $p 16^{I N K 4 A}, p 19^{A R F}$ and $p 21^{W A F 1}$, thus attenuating $p 53$ responses and allowing cancer cells to escape RASinduced senescence in fibroblasts and human mammary epithelial cells [34]. ZEB1 was also shown to suppress $p 16^{I N K 4 A}$ and $p 15^{I N K 4 B}$ expression and enable the overcoming of OIS that is triggered by the overexpression of EGFR (epidermal growth factor receptor) in human esophageal epithelial cells [94]. Moreover, the high expression of EMT-TF ZEB1 in mammary stem cells partly prevents oncogene-induced cell stress, in turn allowing the evasion of oncosuppressive barriers and subsequent malignant transformation. Thus, a stem state can allow a cell to continue to proliferate via senescence bypass, while fending off high DNA damage and genome instability that would typically be acquired during a senescent period [95].

\section{A Dualistic Model for Tumor Initiation}

Together, the modes of action of senescence escape and senescence bypass consolidate a dualistic model for overcoming cell cycle arrest and initiating a tumor (Figure 1). More specifically, the escape from senescence of differentiated cells like fibroblasts requires the acquisition of polyploidy and genomic instability. In contrast, stem cells and undifferentiated cells have the intrinsic propensity to bypass senescence, which relies, at least partly, on the cells' EMT-dependent features of plasticity and is accompanied by the preservation of a normal, stable genome [41,95]. As a result, genomically-stable tumors originate from cells that are able to bypass senescence and evade the onset of genomic instability as observed in tumors originating from senescence-escaped cells $[41,95,96]$. This difference in the mode of tumor initiation further highlights the relevance of the cell of origin in cancer for conditioning entry into senescence and the necessity for escape [96,97]. In view of this, cells of stem or embryonic origin, which largely include pediatric tumors, are able to bypass senescence $[41,95,98]$. 
Cell-of-origin

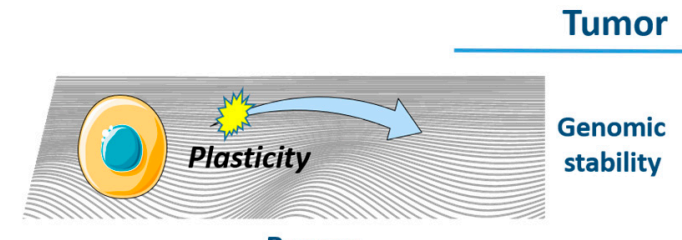

Bypass

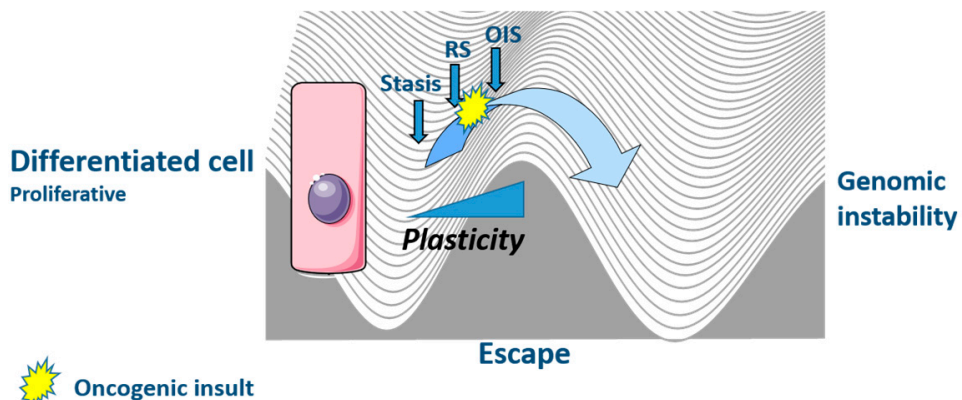

Figure 1. Dualistic model for tumor initiation. Stem cells are quiescent and present intrinsic EMTdependent plasticity features. Stem cells are able to bypass senescence and give rise to genomically stable tumors [95]. Inversely, the escape from senescence of differentiated cells requires the acquisition of polyploidy and extensive cellular reprogramming, resulting in genomically rearranged tumors. Stasis: stress-associated senescence barrier. RS: replicative senescence. OIS: oncogene-induced senescence. This figure was made using elements from Servier Medical Art, which are licensed under a Creative Commons Attribution 3.0 Unported License: https:/ / smart.servier.com (accessed on 17 August 2021).

\section{SASP: A Major Determinant of Tumorigenesis}

The SASP refers to the secretome of senescent cells [2]. As a whole, the SASP comprises a range of substances, including inflammatory cytokines like IL-6 and IL-8, immune modulators, paracrine factors, growth factors and enzymes $[14,99]$. The SASP is typically induced following chemo- or radiotherapy [100]. However, various other types of stress stimuli, including oncogene activation and telomere attrition, can induce the SASP. Depending on the type of stress and type of cell, the SASP varies in composition and over time to produce a unique, cell-specific response [3,5,101-105].

It has been recently proposed to group SASPs into two main types, despite some redundancy in composition: (i) the major inflammation regulator, NF-KB-dependent inflammatory-type SASP (NASP), under the control of the key inflammation mediator, the cGAS/STING/p38/NFKB/IL-1 $\alpha$ axis [102,105-109]; and (ii) the major tumor suppressor, p53-dependent SASP (PASP) (Table 1) [100,107,110]. Even though both types can be found in the same cell population, a dichotomy has indeed been proposed between the two [100,103,110]. Importantly, while the PASP is linked to mitochondrial dysfunction [103], the NASP is found to have tumorigenic properties, thus suggesting a causal link between chronic inflammation and tumor development [110]. Notably, this link is dependent on the paracrine action of NASP factors, which can impact the overall fitness of an entire cell population as compared to the fate of a single cell. For example, OIS-dependent cellular reprogramming via the NASP can lead to population level cellular immortality and carcinogenesis [33,41,111-113], as is found to be important for tumor initiation in transgenic models [114], although seemingly not required for tumor initiation in xenografts [107]. Furthermore, the SASP produced by senescent fibroblasts promotes the cancerous development of nearby epithelial cells through paracrine action and is associated with an increase in epithelial cell proliferation and EMT-mediated plasticity [14,115-118]. While these examples demonstrate the pro-tumor role of the SASP via a paracrine effect, there are few studies that functionally demonstrate a potential role for the SASP in tumorigenesis associated with the escape from or bypass of senescence. 
Table 1. Secreted factors in the NF-KB-dependent inflammatory-type SASP and p53-dependent SASP $[103,110]$.

\begin{tabular}{cc}
\hline Type of SASP & Secreted Factors \\
\hline NF-KB-dependent inflammatory-type SASP & IL1 $\alpha$, Il $\beta$, IL6, IL8, IL10, CXCL1, CXCL2, VEGF, \\
MMP3, TNF $\alpha$, FGF
\end{tabular}

Importantly, the NASP is also strongly linked to innate immunity through the cGAS/ STING/NFKB pathway, notably during wound healing $[5,117,119]$. Here, the recruitment of specialized immune cells via the SASP to a wound site leads to the clearance of senescent cells and thereby shuts off opportunities for these cells to overcome senescence and initiate tumorigenesis (detailed in the next section) [105,107-109].

Thus, in addition to its population-scale pro-tumor effects, the SASP is also involved in anti-tumorigenesis at early stages by targeting individual senescent cells that could potentially become tumorigenic $[107,118,120]$. Many studies report divergent conclusions as to the anti- or pro-tumor role of the SASP [121]. These discrepancies are often attributed to a difference in cell type, stimulus, environmental context or tumor stage [122]. It is also possible that these conclusions depend on the cellular or population-based context, where consideration of the number of cells involved in the SASP is critical for interpretations $[123,124]$.

\section{Acquisition of Plasticity Allows Immunoevasion by Senescent Cells}

Through the SASP, senescent cells recruit immune cells into tissues and bring about their own elimination. Particularly in the non-pathological context of wound healing, senescent cells present at a wound site secrete chemokines like CCL2 as part of the inflammatory secretome, which can attract immature monocytes expressing the chemokine receptor CCR2. These monocytes then become activated into polarized M1 (inflammatory) macrophages that produce interleukins such as IL-1alpha, IL-1beta and IL-6 and allow the recruitment of NK cells to the wound site $[120,124-126]$. NK cells will subsequently recognize and eliminate senescent cells [126-129]. This process of SASP-mediated immune clearance of senescent cells is also enabled by antigen-presenting cells, which play an important role in the activation of T4 lymphocytes under the influence of M1-secreted cytokines [118]. Senescent cells can further promote their elimination by becoming immunogenic through the expression of stimulatory ligands such as MHC Class I chain-related proteins A and $\mathrm{B}$ (MICA/B). MICA/B can bind to the transmembrane receptor NKG2D and activate the killing of senescent cells through the action of NK cells [127,129].

This active role of the immune system in clearing senescent cells means that any impairment of the immune system would result in the persistent accumulation of these cells. Indeed, impaired innate and adaptive immune responses have been reported to result in the increment of various senescent cells, which would become deleterious in the context of tumorigenesis $[130,131]$. Although not completely validated, the acquisition of plasticity by senescent cells has been described to allow immune evasion, for example, after overcoming polyploidy in fibroblasts [77]. This has made it possible to put forward an association between stemness and immune evasion $[132,133]$. However, the stemness state does not intrinsically facilitate immune evasion by senescent cells. Rather, it is due to a downregulation of the antigen presentation pathway as a result of a decrease in replication in quiescent stem cells, which in turn prevents their immunoediting [134,135]. Indeed, studies confirm that, in stem cells, which are a key raw material for tumor initiation (described in previous section), quiescence promotes evasion from the immune system in both physiological [134] and pathological [136-138] contexts. For example, the lack of MHC class I-mediated antigen presentation on the surface of cancer cells is linked to the level of DNA replication and is shown to generate a stress response that enables these $\mathrm{MHCI}^{-}$ 
cancer cells to evade the immune system and establish metastatic foci $[137,139]$. Other modes of immune evasion by senescent cells include alterations to the secretory phenotype during senescence escape. These changes in the composition of the secretome (e.g., overexpression of MMP3, which cleaves activating MICA ligands from the senescent cell surface, or HLA-E-, an inhibitory ligand that blocks NK cell killing) can lead to a redirection of macrophage polarization from a tumor-inhibiting M1 state to a tumor-promoting M2 state that prevents the elimination of senescence-escaped cancer cells $[124,130,131]$. Furthermore, EMT can also lead to reduced immunoediting through the modification of the nature and quantity of antigens presented on the surface of senescent cells due to a downregulation in the expression of immune receptors like MHC-I [140,141] (Figure 2).
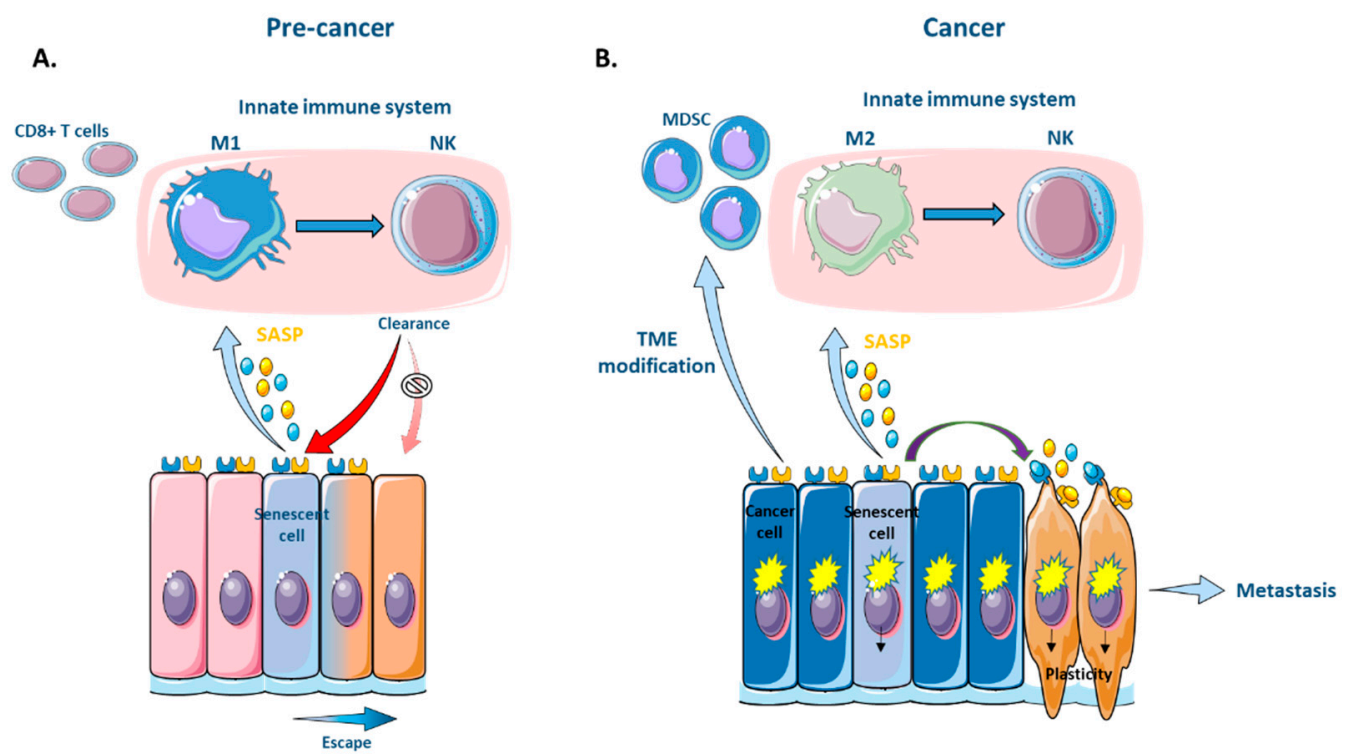

Figure 2. Immune evasion of senescent cells through acquisition of plasticity. (A) The acquisition of plasticity during senescence escape alters the secretory phenotype, leading to a redirection of macrophage polarization, preventing the clearance of senescent cancer cells [124]. EMT/plasticity modulates the expression of immune receptors (downregulated MHC-I) and the recognition of senescent cells by the immune system. (B) The SASP produced by senescent cancer cells leads to the recruitment of immature monocytes (MDSCs). Their maturation is prevented by adjacent cancer cells through metabolic modification of the tumor microenvironment (TME) [142]. The accumulation of MDSCs unable to polarize into M1, nor recruit NKs [143] or CD8+ T cells, in turn leads to the creation of an immune umbrella for cancer cell growth and will promote metastatic progression via the enhancement of EMT. This figure was made using elements from Servier Medical Art, which are licensed under a Creative Commons Attribution 3.0 Unported License: https: / / smart.servier.com (accessed on 17 August 2021).

\section{Senescence Escape Is a Driver of Tumor Resilience}

Evasion or escape from therapy-induced senescence (TIS) has been reported in several cancer cases [144,145]. In fact, cancer cells that spontaneously escape senescence have been found to have genomic alterations, notably, a polyploid phenotype characterized by the presence of polyploid giant cells [56,146-148]. These observations are in line with reports of approximately one-third of tumors being polyploid [149,150], while additional studies carried out both in vitro and in vivo further demonstrate polyploidy in cancer cells [85,151-155]. Thus, similar to pre-tumoral senescent cells (refer Section 1), polyploidy has been described as a means of senescence escape in cancer cells [152].

Importantly, by facilitating escape, the polyploid phenotype promotes the resilience and stability of cancer cells. The senescence escape of polyploid cancer cells is associated with depolyploidization (neosis), a reverse process that can reprogram these cells to return to the mitotic cell cycle via epigenetic silencing of the cell cycle inhibitor, p21 WAF1. These mitotically propagating, paradiploid-descendent tumor cells also exhibit a transcriptomic 
profile correlated with cytokine reprogramming. More specifically, the increased expression of pro-inflammatory cytokines, comprising IL-1beta, IL-6 and IL-8, strongly activates the TGF-beta pathway, resulting in the acquisition of EMT features, including a mesenchymal phenotype, as well as the upregulation of EMT markers $[89,153,156]$. These events are also accompanied by the upregulation of stemness markers $[89,151,153,157,158]$ and tumorigenic and metastatic capacities, further suggesting a certain phenotypic stability and resilience of these daughter cells over time [109,151,159,160].

Collectively, these data demonstrate that polyploidy associated with TIS escape may play a central role in the survival of some cancer cells through the acquisition of a mesenchymal phenotype. This will lead to eventual clonogenic re-growth of a tumor following genotoxic stress induced by radio- or chemotherapy $[76,87,151,152,161-165]$.

\section{Cellular Plasticity Can Result from an Interplay between Senescent Cells and the Immune Component}

Senescent cells are the only type of cells capable of producing the so-called "secretory phenotype" (SASP). However, through the paracrine action of SASP factors like TGF-beta and the inflammatory cytokine IL-6, senescent cells can impact various regulatory circuits that are common between the immune system and the EMT program [54,166-168]. While an increase in this paracrine effect is observed following loss of the tumor suppressor p53, paracrine activity is further supported by patterns of epigenetic reprogramming (e.g., novel methylation landscapes) that are memorized by cells, even after overcoming senescence, as well as by the sustenance of active transcriptomic profiles for senescence and SASP-related genes $[77,99,107,109,169]$.

The paracrine action of SASP factors can indeed be pro-tumoral via its effect on EMT, given the widely demonstrated role of EMT in invasion and metastatic dissemination $[99,122,170,171]$ (Figure 3). In this context, genotoxic stress from OIS or TIS leads to the generation of micronuclei and genomic instability, preceding the activation of an inflammatory secretory phenotype controlled by the cGAS/STING/NFKB pathway $[105,107-109,172]$. Activation of the inflammatory SASP enhances migration and invasion properties that promote metastasis [173-175]. In this way, a few senescent cancer cells can trigger an increase in the number of cancer cells despite chemo- or radiotherapeutic treatments $[45,76,99,100,173,176-181]$. Nevertheless, although reports remain merely correlative as to the causal action of EMT, stemness or intrinsic plasticity in chemoresistance [170], it has been shown that resistance to treatment is not so much related to stemness as quiescence, highlighting the contrasting properties of quiescent and therapy-resistant cancer stem cells [182-185].

Recent findings reveal an interplay between the activation of the SASP and the composition of the tumor microenvironment (TME). Specifically, the SASP can modulate the population of immunosuppressive cells in the TME. Immature monocytes (MDSCs) are typically recruited to a site of senescence. However, the maturation of these MDSCs into a tumor-inhibiting M1 state can be prevented by adjacent cancer cells through lactate production as a result of their glycolytic metabolism [142]. This results in an inability to recruit NK lymphocytes [143] or CD8+ T cells. NK cells play an important role in hindering the EMT of cancer cells during metastatic progression. This is due to an increased susceptibility of cancer cells to NK cytotoxicity associated with the EMT phenotype (e.g., lowered e-cadherin) [186]. Thus, through modifications to the TME, the absence of NKmediated clearance ultimately creates an immune umbrella over senescent cancer cells and creates a permissive environment for cancer cell growth and metastatic progression via the enhancement of EMT [186-188] (Figures 2 and 3).

Finally, beyond epithelial cancer cells, even adjacent normal fibroblasts can undergo senescence and fuel tumor progression [189]. Yet the data remains unclear as to the autocrine and/or paracrine action of the SASP as well as other SASP factors that could contribute to invasion and dissemination via increased angiogenesis [190]. 


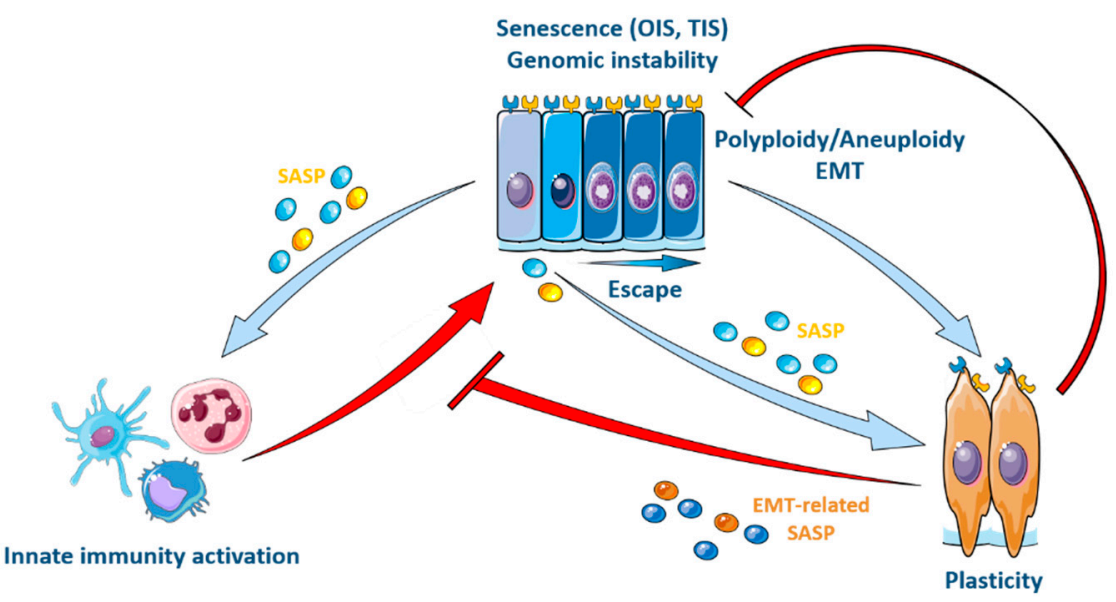

Figure 3. Plasticity acquired following senescence escape leads to the modulation of innate immunity. Senescence induced by different stimuli activates the production of an inflammatory secretory phenotype (SASP) under the control of the cGAS/STING/NFKB pathway. Its activation is required for the recruitment of immune cells and the clearance of senescent cancer cells by the innate immune system. On the other hand, SASP, together with polyploidy and EMT features acquired after escape from senescence, leads to the enhanced cancer cell plasticity associated with a deleterious secretory phenotype, allowing immune evasion of cancer cells. This figure was made using elements from Servier Medical Art, which are licensed under a Creative Commons Attribution 3.0 Unported License: https:/ / smart.servier.com (accessed on 17 August 2021).

\section{Conclusions}

Senescence is essential for the sustenance of physiological processes like embryonic development and wound healing. However, senescence can also have more prolonged, negative effects that contribute to deteriorative conditions like fibrosis and cancer. By definition, a senescent cell is a cell that has exited the cell cycle and therefore lacks proliferative capacity. Thus, following an oncogenic insult, the entry into senescence is considered an oncosuppressive process. Yet, through the accumulation of cell-autonomous features like genetic and epigenetic changes during the senescent period, an individual cell can escape from senescence while becoming plastic. Moreover, via cell non-autonomous features like the SASP, which has a paracrine mode of action, tumorigenic capacities can be imparted to entire cell populations. Hence, senescence escape as well as population-level reprogramming through the SASP are essential pathways for the progression of epithelial tumors. The acquisition of plasticity by EMT can also allow cells to completely avoid senescence. The propensity of a cell to bypass OIS is determined by the state of cellular differentiation and has a major impact on the genetic history of tumor development. Furthermore, the immune system is intricately involved in senescence-mediated pro-tumor effects. First, an increasing flow of senescent cells during tumor progression can embolize the immune system and alter the composition of the SASP according to the genetic background of cells, thus modulating immunoediting of these cells. Second, the presence of cancer cells can modify the tumor microenvironment, notably through the release of lactic acid, preventing the elimination by the immune system of senescent cancer cells that are already present or are emerging. Finally, it is important to distinguish the precancerous stage at which the NASP and the PASP regulate the elimination of potentially cancerous senescent cells. Similarly, the cancer stage at which the NASP allows for an increased plasticity and aggressiveness of tumor cells must also be determined. A potential and novel therapeutic avenue would be to target the NASP-mediated plasticity of tumor cells, with the aim of hindering the underlying migratory and metastatic properties.

Author Contributions: Conceptualization, A.P. and H.D.B.; writing-original draft preparation, H.D.B., A.-P.M., A.P.S. and M.O.; writing-review and editing, all authors; supervision, A.P. All authors have read and agreed to the published version of the manuscript. 
Funding: This research received no external funding.

Acknowledgments: H.D.B. is supported by Fondation pour la recherche médicale (FRM); A.P., M.O. and A.-P.M. are supported by funding from the Ligue Nationale contre le Cancer and from the Project National Cancer Association, Lyon Integrated Research Institute in Cancer (LYRIC, INCa 4664); A.P.S. is supported by Institut Curie.

Conflicts of Interest: The authors declare no conflict of interest.

\section{References}

1. Muñoz-Espín, D.; Serrano, M. Cellular Senescence: From Physiology to Pathology. Nat. Rev. Mol. Cell Biol. 2014, 15, 482-496. [CrossRef]

2. Salama, R.; Sadaie, M.; Hoare, M.; Narita, M. Cellular Senescence and Its Effector Programs. Genes Dev. 2014, $28,99-114$. [CrossRef] [PubMed]

3. Hernandez-Segura, A.; Nehme, J.; Demaria, M. Hallmarks of Cellular Senescence. Trends Cell Biol. 2017, 28, 436-453. [CrossRef] [PubMed]

4. Abbadie, C.; Pluquet, O.; Pourtier, A. Epithelial Cell Senescence: An Adaptive Response to Pre-Carcinogenic Stresses? Cell. Mol. Life Sci. 2017, 74, 4471-4509. [CrossRef]

5. $\quad$ Demaria, M.; Ohtani, N.; Youssef, S.A.; Rodier, F.; Toussaint, W.; Mitchell, J.R.; Laberge, R.-M.; Vijg, J.; Van Steeg, H.; Dollé, M.E.T.; et al. An Essential Role for Senescent Cells in Optimal Wound Healing through Secretion of PDGF-AA. Dev. Cell 2014, $31,722-733$. [CrossRef]

6. Ritschka, B.; Storer, M.; Mas, A.; Heinzmann, F.; Ortells, M.C.; Morton, J.P.; Sansom, O.J.; Zender, L.; Keyes, W.M. The SenescenceAssociated Secretory Phenotype Induces Cellular Plasticity and Tissue Regeneration. Genes Dev. 2017, 31, 172-183. [CrossRef]

7. Hiebert, P.; Wietecha, M.S.; Cangkrama, M.; Haertel, E.; Mavrogonatou, E.; Stumpe, M.; Steenbock, H.; Grossi, S.; Beer, H.-D.; Angel, P.; et al. Nrf2-Mediated Fibroblast Reprogramming Drives Cellular Senescence by Targeting the Matrisome. Dev. Cell 2018, 46, 145-161.e10. [CrossRef] [PubMed]

8. Da Silva-Álvarez, S.; Guerra-Varela, J.; Sobrido-Cameán, D.; Quelle, A.; Barreiro-Iglesias, A.; Sánchez, L.; Collado, M. Cell Senescence Contributes to Tissue Regeneration in Zebrafish. Aging Cell 2020, 19, e13052. [CrossRef]

9. Hinz, B. The Role of Myofibroblasts in Wound Healing. Curr. Res. Transl. Med. 2016, 64, 171-177. [CrossRef]

10. Desmoulière, A.; Redard, M.; Darby, I.; Gabbiani, G. Apoptosis Mediates the Decrease in Cellularity during the Transition between Granulation Tissue and Scar. Am. J. Pathol. 1995, 146, 56-66.

11. Jeon, O.H.; Kim, C.; Laberge, R.-M.; Demaria, M.; Rathod, S.; Vasserot, A.P.; Chung, J.W.; Kim, D.H.; Poon, Y.; David, N.; et al. Local Clearance of Senescent Cells Attenuates the Development of Post-Traumatic Osteoarthritis and Creates a pro-Regenerative Environment. Nat. Med. 2017, 23, 775-781. [CrossRef]

12. Schafer, M.J.; White, T.A.; Iijima, K.; Haak, A.J.; Ligresti, G.; Atkinson, E.J.; Oberg, A.L.; Birch, J.; Salmonowicz, H.; Zhu, Y.; et al. Cellular Senescence Mediates Fibrotic Pulmonary Disease. Nat. Commun. 2017, 8, 14532. [CrossRef]

13. Wiley, C.D.; Brumwell, A.N.; Davis, S.S.; Jackson, J.R.; Valdovinos, A.; Calhoun, C.; Alimirah, F.; Castellanos, C.A.; Ruan, R.; Wei, Y.; et al. Secretion of Leukotrienes by Senescent Lung Fibroblasts Promotes Pulmonary Fibrosis. JCI Insight 2019, 4, e130056. [CrossRef]

14. Krtolica, A.; Parrinello, S.; Lockett, S.; Desprez, P.Y.; Campisi, J. Senescent Fibroblasts Promote Epithelial Cell Growth and Tumorigenesis: A Link between Cancer and Aging. Proc. Natl. Acad. Sci. USA 2001, 98, 12072-12077. [CrossRef] [PubMed]

15. Cirri, P.; Chiarugi, P. Cancer Associated Fibroblasts: The Dark Side of the Coin. Am. J. Cancer Res. 2011, 1, 482-497. [PubMed]

16. Burd, C.E.; Sorrentino, J.A.; Clark, K.S.; Darr, D.B.; Krishnamurthy, J.; Deal, A.M.; Bardeesy, N.; Castrillon, D.H.; Beach, D.H.; Sharpless, N.E. Monitoring Tumorigenesis and Senescence in Vivo with a P16INK4a-Luciferase Model. Cell 2013, 152, 340-351. [CrossRef]

17. Dvorak, H.F. Tumors: Wounds That Do Not Heal. Similarities between Tumor Stroma Generation and Wound Healing. N. Engl. J. Med. 1986, 315, 1650-1659. [CrossRef]

18. MacCarthy-Morrogh, L.; Martin, P. The Hallmarks of Cancer Are Also the Hallmarks of Wound Healing. Sci. Signal. 2020, 13, 648. [CrossRef]

19. O'Byrne, K.J.; Dalgleish, A.G. Chronic Immune Activation and Inflammation as the Cause of Malignancy. Br. J. Cancer 2001, 85, 473-483. [CrossRef] [PubMed]

20. Nieto, M.A.; Huang, R.Y.-J.; Jackson, R.A.; Thiery, J.P. EMT: 2016. Cell 2016, 166, 21-45. [CrossRef]

21. Schiebinger, G.; Shu, J.; Tabaka, M.; Cleary, B.; Subramanian, V.; Solomon, A.; Gould, J.; Liu, S.; Lin, S.; Berube, P.; et al. OptimalTransport Analysis of Single-Cell Gene Expression Identifies Developmental Trajectories in Reprogramming. Cell 2019, 176, 928-943.e22. [CrossRef] [PubMed]

22. Grosse-Wilde, A.; D’Hérouël, A.F.; McIntosh, E.; Ertaylan, G.; Skupin, A.; Kuestner, R.E.; Del Sol, A.; Walters, K.A.; Huang, S. Stemness of the Hybrid Epithelial/Mesenchymal State in Breast Cancer and Its Association with Poor Survival. PLoS ONE 2015, 10, e0126522. [CrossRef] 
23. Grande, M.T.; Sánchez-Laorden, B.; López-Blau, C.; De Frutos, C.A.; Boutet, A.; Arévalo, M.; Rowe, R.G.; Weiss, S.J.; López-Novoa, J.M.; Nieto, M.A. Snail1-Induced Partial Epithelial-to-Mesenchymal Transition Drives Renal Fibrosis in Mice and Can Be Targeted to Reverse Established Disease. Nat. Med. 2015, 21, 989-997. [CrossRef]

24. Lovisa, S.; LeBleu, V.S.; Tampe, B.; Sugimoto, H.; Vadnagara, K.; Carstens, J.L.; Wu, C.-C.; Hagos, Y.; Burckhardt, B.C.; PentchevaHoang, T.; et al. Epithelial-to-Mesenchymal Transition Induces Cell Cycle Arrest and Parenchymal Damage in Renal Fibrosis. Nat. Med. 2015, 21, 998-1009. [CrossRef]

25. Adams, T.S.; Schupp, J.C.; Poli, S.; Ayaub, E.A.; Neumark, N.; Ahangari, F.; Chu, S.G.; Raby, B.A.; DeIuliis, G.; Januszyk, M.; et al. Single-Cell RNA-Seq Reveals Ectopic and Aberrant Lung-Resident Cell Populations in Idiopathic Pulmonary Fibrosis. Sci. Adv. 2020, 6, eaba1983. [CrossRef]

26. Choi, J.; Park, J.-E.; Tsagkogeorga, G.; Yanagita, M.; Koo, B.-K.; Han, N.; Lee, J.-H. Inflammatory Signals Induce AT2 Cell-Derived Damage-Associated Transient Progenitors That Mediate Alveolar Regeneration. Cell Stem Cell 2020, 27, 366-382.e7. [CrossRef]

27. Habermann, A.C.; Gutierrez, A.J.; Bui, L.T.; Yahn, S.L.; Winters, N.I.; Calvi, C.L.; Peter, L.; Chung, M.-I.; Taylor, C.J.; Jetter, C.; et al. Single-Cell RNA Sequencing Reveals Profibrotic Roles of Distinct Epithelial and Mesenchymal Lineages in Pulmonary Fibrosis. Sci. Adv. 2020, 6, eaba1972. [CrossRef]

28. Kobayashi, Y.; Tata, A.; Konkimalla, A.; Katsura, H.; Lee, R.F.; Ou, J.; Banovich, N.E.; Kropski, J.A.; Tata, P.R. Persistence of a Regeneration-Associated, Transitional Alveolar Epithelial Cell State in Pulmonary Fibrosis. Nat. Cell Biol. 2020, 22, 934-946. [CrossRef]

29. Strunz, M.; Simon, L.M.; Ansari, M.; Kathiriya, J.J.; Angelidis, I.; Mayr, C.H.; Tsidiridis, G.; Lange, M.; Mattner, L.F.; Yee, M.; et al. Alveolar Regeneration through a Krt8+ Transitional Stem Cell State That Persists in Human Lung Fibrosis. Nat. Commun. 2020, 11, 3559. [CrossRef] [PubMed]

30. Ocampo, A.; Reddy, P.; Martinez-Redondo, P.; Platero-Luengo, A.; Hatanaka, F.; Hishida, T.; Li, M.; Lam, D.; Kurita, M.; Beyret, E.; et al. In Vivo Amelioration of Age-Associated Hallmarks by Partial Reprogramming. Cell 2016, 167, 1719-1733.e12. [CrossRef] [PubMed]

31. Doeser, M.C.; Schöler, H.R.; Wu, G. Reduction of Fibrosis and Scar Formation by Partial Reprogramming In Vivo. Stem Cells 2018, 36, 1216-1225. [CrossRef] [PubMed]

32. de Lázaro, I.; Yilmazer, A.; Nam, Y.; Qubisi, S.; Razak, F.M.A.; Degens, H.; Cossu, G.; Kostarelos, K. Non-Viral, Tumor-Free Induction of Transient Cell Reprogramming in Mouse Skeletal Muscle to Enhance Tissue Regeneration. Mol. Ther. 2019, 27, 59-75. [CrossRef] [PubMed]

33. Mosteiro, L.; Pantoja, C.; Alcazar, N.; Marión, R.M.; Chondronasiou, D.; Rovira, M.; Fernandez-Marcos, P.J.; Muñoz-Martin, M.; Blanco-Aparicio, C.; Pastor, J.; et al. Tissue Damage and Senescence Provide Critical Signals for Cellular Reprogramming in Vivo. Science 2016, 354, aaf4445. [CrossRef]

34. Ansieau, S.; Bastid, J.; Doreau, A.; Morel, A.-P.P.; Bouchet, B.P.; Thomas, C.; Fauvet, F.; Puisieux, I.; Doglioni, C.; Piccinin, S.; et al. Induction of EMT by Twist Proteins as a Collateral Effect of Tumor-Promoting Inactivation of Premature Senescence. Cancer Cell 2008, 14, 79-89. [CrossRef]

35. Morel, A.-P.; Hinkal, G.W.; Thomas, C.; Fauvet, F.; Courtois-Cox, S.; Wierinckx, A.; Devouassoux-Shisheboran, M.; Treilleux, I.; Tissier, A.; Gras, B.; et al. EMT Inducers Catalyze Malignant Transformation of Mammary Epithelial Cells and Drive Tumorigenesis towards Claudin-Low Tumors in Transgenic Mice. PLoS Genet. 2012, 8, e1002723. [CrossRef]

36. Collado, M.; Blasco, M.A.; Serrano, M. Cellular Senescence in Cancer and Aging. Cell 2007, 130, 223-233. [CrossRef]

37. Hanahan, D.; Weinberg, R.A. Hallmarks of Cancer: The Next Generation. Cell 2011, 144, 646-674. [CrossRef]

38. Childs, B.G.; Gluscevic, M.; Baker, D.J.; Laberge, R.-M.; Marquess, D.; Dananberg, J.; van Deursen, J.M. Senescent Cells: An Emerging Target for Diseases of Ageing. Nat. Rev. Drug Discov. 2017, 16, 718-735. [CrossRef]

39. Maciejowski, J.; de Lange, T. Telomeres in Cancer: Tumour Suppression and Genome Instability. Nat. Rev. Mol. Cell Biol. 2017, 18, 175-186. [CrossRef] [PubMed]

40. Faget, D.V.; Ren, Q.; Stewart, S.A. Unmasking Senescence: Context-Dependent Effects of SASP in Cancer. Nat. Rev. Cancer 2019, 19, 439-453. [CrossRef] [PubMed]

41. Puisieux, A.; Pommier, R.M.; Morel, A.P.; Lavial, F. Cellular Pliancy and the Multistep Process of Tumorigenesis. Cancer Cell 2018, 33, 164-172. [CrossRef]

42. Puisieux, A.; Brabletz, T.; Caramel, J. Oncogenic Roles of EMT-Inducing Transcription Factors. Nat. Cell Biol. 2014, 16, 488-494. [CrossRef] [PubMed]

43. Braig, M.; Lee, S.; Loddenkemper, C.; Rudolph, C.; Peters, A.H.F.M.; Schlegelberger, B.; Stein, H.; Dörken, B.; Jenuwein, T.; Schmitt, C.A. Oncogene-Induced Senescence as an Initial Barrier in Lymphoma Development. Nature 2005, 436, 660-665. [CrossRef] [PubMed]

44. Chen, Z.; Trotman, L.C.; Shaffer, D.; Lin, H.-K.; Dotan, Z.A.; Niki, M.; Koutcher, J.A.; Scher, H.I.; Ludwig, T.; Gerald, W.; et al. Crucial Role of P53-Dependent Cellular Senescence in Suppression of Pten-Deficient Tumorigenesis. Nature 2005, 436, 725-730. [CrossRef] [PubMed]

45. Michaloglou, C.; Vredeveld, L.C.W.; Soengas, M.S.; Denoyelle, C.; Kuilman, T.; Van Der Horst, C.M.A.M.; Majoor, D.M.; Shay, J.W.; Mooi, W.J.; Peeper, D.S. BRAFE600-Associated Senescence-like Cell Cycle Arrest of Human Naevi. Nature 2005, 436, 720-724. [CrossRef] 
46. Aird, K.M.; Zhang, G.; Li, H.; Tu, Z.; Bitler, B.G.; Garipov, A.; Wu, H.; Wei, Z.; Wagner, S.N.; Herlyn, M.; et al. Suppression of Nucleotide Metabolism Underlies the Establishment and Maintenance of Oncogene-Induced Senescence. Cell Rep. 2013, 3, 1252-1265. [CrossRef]

47. Böhme, I.; Bosserhoff, A. Extracellular Acidosis Triggers a Senescence-like Phenotype in Human Melanoma Cells. Pigment Cell Melanoma Res. 2020, 33, 41-51. [CrossRef]

48. Nassour, J.; Martien, S.; Martin, N.; Deruy, E.; Tomellini, E.; Malaquin, N.; Bouali, F.; Sabatier, L.; Wernert, N.; Pinte, S.; et al. Defective \{DNA\} Single-Strand Break Repair Is Responsible for Senescence and Neoplastic Escape of Epithelial Cells. Nat. Commun. 2016, 7, 10399. [CrossRef]

49. Gosselin, K.; Martien, S.; Pourtier, A.; Vercamer, C.; Ostoich, P.; Morat, L.; Sabatier, L.; Duprez, L.; de Roodenbeke, C.; Gilson, E.; et al. Senescence-Associated Oxidative $\{$ DNA $\}$ Damage Promotes the Generation of Neoplastic Cells. Cancer Res. 2009, 69, 7917-7925. [CrossRef] [PubMed]

50. Brenner, A.J.; Stampfer, M.R.; Aldaz, C.M. Increased P16 Expression with First Senescence Arrest in Human Mammary Epithelial Cells and Extended Growth Capacity with P16 Inactivation. Oncogene 1998, 17, 199-205. [CrossRef] [PubMed]

51. Jang, D.H.; Bhawal, U.K.; Min, H.K.; Kang, H.K.; Abiko, Y.; Min, B.M. A Transcriptional Roadmap to the Senescence and Differentiation of Human Oral Keratinocytes. J. Gerontol.-Ser. A Biol. Sci. Med. Sci. 2015, 70, 20-32. [CrossRef] [PubMed]

52. Rheinwald, J.G.; Hahn, W.C.; Ramsey, M.R.; Wu, J.Y.; Guo, Z.; Tsao, H.; De Luca, M.; Catricalà, C.; O’Toole, K.M. A Two-Stage, P16 INK4A-and P53-Dependent Keratinocyte Senescence Mechanism That Limits Replicative Potential Independent of Telomere Status. Mol. Cell. Biol. 2002, 22, 5157-5172. [CrossRef] [PubMed]

53. Feijoo, P.; Terradas, M.; Soler, D.; Domínguez, D.; Tusell, L.; Genescà, A. Breast Primary Epithelial Cells That Escape P16Dependent Stasis Enter a Telomeredriven Crisis State. Breast Cancer Res. 2016, 18, 7. [CrossRef] [PubMed]

54. Martin, N.; Cardozo, C.S.; Vercamer, C.; Ott, L.; Marot, G.; Slijepcevic, P.; Abbadie, C.; Pluquet, O. Identification of a Gene Signature of a Pre-Transformation Process by Senescence Evasion in Normal Human Epidermal Keratinocytes. Mol. Cancer 2014, 13, 151. [CrossRef] [PubMed]

55. Gosselin, K.; Deruy, E.; Martien, S.; Vercamer, C.; Bouali, F.; Dujardin, T.; Slomianny, C.; Houel-Renault, L.; Chelli, F.; De Launoit, Y.; et al. Senescent Keratinocytes Die by Autophagic Programmed Cell Death. Am. J. Pathol. 2009, 174, 423-435. [CrossRef]

56. Romanov, S.R.; Kozakiewicz, B.K.; Holst, C.R.; Stampfer, M.R.; Haupt, L.M.; Tlsty, T.D. Normal Human Mammary Epithelial Cells Spontaneously Escape Senescence and Acquire Genomic Changes. Nature 2001, 409, 633-637. [CrossRef]

57. Novak, P.; Jensen, T.J.; Garbe, J.C.; Stampfer, M.R.; Futscher, B.W. Stepwise DNA Methylation Changes Are Linked to Escape from Defined Proliferation Barriers and Mammary Epithelial Cell Immortalization. Cancer Res. 2009, 69, 5251-5258. [CrossRef]

58. Tamayo-Orrego, L.; Wu, C.-L.; Bouchard, N.; Khedher, A.; Swikert, S.M.; Remke, M.; Skowron, P.; Taylor, M.D.; Charron, F. Evasion of Cell Senescence Leads to Medulloblastoma Progression. Cell Rep. 2016, 14, 2925-2937. [CrossRef]

59. Shain, A.H.; Yeh, I.; Kovalyshyn, I.; Sriharan, A.; Talevich, E.; Gagnon, A.; Dummer, R.; North, J.; Pincus, L.; Ruben, B.; et al. The Genetic Evolution of Melanoma from Precursor Lesions. N. Engl. J. Med. 2015, 373, 1926-1936. [CrossRef]

60. Bernstein, D.L.; Le Lay, J.E.; Ruano, E.G.; Kaestner, K.H. TALE-Mediated Epigenetic Suppression of CDKN2A Increases Replication in Human Fibroblasts. J. Clin. Investig. 2015, 125, 1998-2006. [CrossRef]

61. Morel, A.P.; Lievre, M.; Thomas, C.; Hinkal, G.; Ansieau, S.; Puisieux, A. Generation of Breast Cancer Stem Cells through Epithelial-Mesenchymal Transition. PLoS ONE 2008, 3, e2888. [CrossRef]

62. Mani, S.A.; Guo, W.; Liao, M.-J.J.; Eaton, E.N.; Ayyanan, A.; Zhou, A.Y.; Brooks, M.; Reinhard, F.; Zhang, C.C.; Shipitsin, M.; et al. The Epithelial-Mesenchymal Transition Generates Cells with Properties of Stem Cells. Cell 2008, 133, 704-715. [CrossRef]

63. Kumar, M.; Jaiswal, R.K.; Prasad, R.; Yadav, S.S.; Kumar, A.; Yadava, P.K.; Singh, R.P. PARP-1 Induces EMT in Non-Small Cell Lung Carcinoma Cells via Modulating the Transcription Factors Smad4, P65 and ZEB1. Life Sci. 2021, 269, 118994. [CrossRef]

64. Pu, H.; Horbinski, C.; Hensley, P.J.; Matuszak, E.A.; Atkinson, T.; Kyprianou, N. PARP-1 Regulates Epithelial-Mesenchymal Transition (EMT) in Prostate Tumorigenesis. Carcinogenesis 2014, 35, 2592-2601. [CrossRef] [PubMed]

65. Rodríguez, M.I.; González-Flores, A.; Dantzer, F.; Collard, J.; De Herreros, A.G.; Oliver, F.J. Poly(ADP-Ribose)-Dependent Regulation of Snail1 Protein Stability. Oncogene 2011, 30, 4365-4372. [CrossRef] [PubMed]

66. Serrano, M.; Lin, A.W.; McCurrach, M.E.; Beach, D.; Lowe, S.W. Oncogenic Ras Provokes Premature Cell Senescence Associated with Accumulation of P53 and P16(INK4a). Cell 1997, 88, 593-602. [CrossRef]

67. Meeker, A.K.; Argani, P. Telomere Shortening Occurs Early during Breast Tumorigenesis: A Cause of Chromosome Destabilization Underlying Malignant Transformation? J. Mammary Gland Biol. Neoplasia 2004, 9, 285-296. [CrossRef] [PubMed]

68. Castro-Vega, L.J.; Jouravleva, K.; Liu, W.-Y.; Martinez, C.; Gestraud, P.; Hupé, P.; Servant, N.; Albaud, B.; Gentien, D.; Gad, S.; et al. Telomere Crisis in Kidney Epithelial Cells Promotes the Acquisition of a MicroRNA Signature Retrieved in Aggressive Renal Cell Carcinomas. Carcinogenesis 2013, 34,1173-1180. [CrossRef]

69. Kuznetsova, A.Y.; Seget, K.; Moeller, G.K.; de Pagter, M.S.; de Roos, J.A.D.M.; Dürrbaum, M.; Kuffer, C.; Müller, S.; Zaman, G.J.R.; Kloosterman, W.P.; et al. Chromosomal Instability, Tolerance of Mitotic Errors and Multidrug Resistance Are Promoted by Tetraploidization in Human Cells. Cell Cycle 2015, 14, 2810-2820. [CrossRef]

70. Galanos, P.; Vougas, K.; Walter, D.; Polyzos, A.; Maya-Mendoza, A.; Haagensen, E.J.; Kokkalis, A.; Roumelioti, F.-M.; Gagos, S.; Tzetis, M.; et al. Chronic P53-Independent P21 Expression Causes Genomic Instability by Deregulating Replication Licensing. Nat. Cell Biol. 2016, 18, 777-789. [CrossRef] 
71. Komseli, E.-S.; Pateras, I.S.; Krejsgaard, T.; Stawiski, K.; Rizou, S.V.; Polyzos, A.; Roumelioti, F.-M.; Chiourea, M.; Mourkioti, I.; Paparouna, E.; et al. A Prototypical Non-Malignant Epithelial Model to Study Genome Dynamics and Concurrently Monitor Micro-RNAs and Proteins in Situ during Oncogene-Induced Senescence. BMC Genom. 2018, 19, 37. [CrossRef]

72. Zampetidis, C.; Galanos, P.; Angelopoulou, A.; Zhu, Y.; Karamitros, T.; Polyzou, A.; Mourkioti, I.; Lagopati, N.; Mirzazadeh, R.; Polyzos, A.; et al. Genomic Instability Is an Early Event Driving Chromatin Reorganization and Escape from Oncogene-Induced Senescence. bioRxiv 2020. [CrossRef]

73. Matsumoto, T.; Wakefield, L.; Peters, A.; Peto, M.; Spellman, P.; Grompe, M. Proliferative Polyploid Cells Give Rise to Tumors via Ploidy Reduction. Nat. Commun. 2021, 12, 646. [CrossRef]

74. Fujiwara, T.; Bandi, M.; Nitta, M.; Ivanova, E.V.; Bronson, R.T.; Pellman, D. Cytokinesis Failure Generating Tetraploids Promotes Tumorigenesis in P53-Null Cells. Nature 2005, 437, 1043-1047. [CrossRef] [PubMed]

75. Davoli, T.; de Lange, T. Telomere-Driven Tetraploidization Occurs in Human Cells Undergoing Crisis and Promotes Transformation of Mouse Cells. Cancer Cell 2012, 21, 765-776. [CrossRef] [PubMed]

76. Zheng, L.; Dai, H.; Zhou, M.; Li, X.; Liu, C.; Guo, Z.; Wu, X.; Wu, J.; Wang, C.; Zhong, J.; et al. Polyploid Cells Rewire DNA Damage Response Networks to Overcome Replication Stress-Induced Barriers for Tumour Progression. Nat. Commun. 2012, 3 , 815. [CrossRef] [PubMed]

77. Leikam, C.; Hufnagel, A.L.; Otto, C.; Murphy, D.J.; Mühling, B.; Kneitz, S.; Nanda, I.; Schmid, M.; Wagner, T.U.; Haferkamp, S.; et al. In Vitro Evidence for Senescent Multinucleated Melanocytes as a Source for Tumor-Initiating Cells. Cell Death Dis. 2015, 6, e1711. [CrossRef]

78. Lin, H.; Huang, Y.-S.; Fustin, J.-M.; Doi, M.; Chen, H.; Lai, H.-H.; Lin, S.-H.; Lee, Y.-L.; King, P.-C.; Hou, H.-S.; et al. Hyperpolyploidization of Hepatocyte Initiates Preneoplastic Lesion Formation in the Liver. Nat. Commun. 2021, 12, 645. [CrossRef]

79. He, Q.; Au, B.; Kulkarni, M.; Shen, Y.; Lim, K.J.; Maimaiti, J.; Wong, C.K.; Luijten, M.N.H.; Chong, H.C.; Lim, E.H.; et al. Chromosomal Instability-Induced Senescence Potentiates Cell Non-Autonomous Tumourigenic Effects. Oncogenesis $2018,7,32$. [CrossRef]

80. Rajaraman, R.; Guernsey, D.L.; Rajaraman, M.M.; Rajaraman, S.R. Stem Cells, Senescence, Neosis and Self-Renewal in Cancer. Cancer Cell Int. 2006, 6, 25. [CrossRef]

81. Walen, K.H. Spontaneous Cell Transformation: Karyoplasts Derived from Multinucleated Cells Produce New Cell Growth in Senescent Human Epithelial Cell Cultures. Vitr. Cell. Dev. Biol.-Anim. 2004, 40, 150-158. [CrossRef]

82. Sundaram, M.; Guernsey, D.L.; Rajaraman, M.M.; Rajaraman, R. Neosis: A Novel Type of Cell Division in Cancer. Cancer Biol. Ther. 2004, 3, 207-218. [CrossRef] [PubMed]

83. Zhang, S.; Mercado-Uribe, I.; Sood, A.; Bast, R.C.; Liu, J. Coevolution of Neoplastic Epithelial Cells and Multilineage Stroma via Polyploid Giant Cells during Immortalization and Transformation of Mullerian Epithelial Cells. Genes Cancer 2016, 7, 60-72. [CrossRef] [PubMed]

84. Erenpreisa, J.A.; Cragg, M.S.; Fringes, B.; Sharakhov, I.; Illidge, T.M. Release of Mitotic Descendants by Giant Cells from Irradiated Burkitt's Lymphoma Cell Line. Cell Biol. Int. 2000, 24, 635-648. [CrossRef]

85. Illidge, T.M.; Cragg, M.S.; Fringes, B.; Olive, P.; Erenpreisa, J.A. Polyploid Giant Cells Provide a Survival Mechanism for P53 Mutant Cells after \{DNA\} Damage. Cell Biol. Int. 2000, 24, 621-633. [CrossRef] [PubMed]

86. Erenpreisa, J.; Cragg, M.S. Three Steps to the Immortality of Cancer Cells: Senescence, Polyploidy and Self-Renewal. Cancer Cell Int. 2013, 13, 92. [CrossRef]

87. Díaz-Carballo, D.; Gustmann, S.; Jastrow, H.; Acikelli, A.H.; Dammann, P.; Klein, J.; Dembinski, U.; Bardenheuer, W.; Malak, S.; Araúzo-Bravo, M.J.; et al. Atypical Cell Populations Associated with Acquired Resistance to Cytostatics and Cancer Stem Cell Features: The Role of Mitochondria in Nuclear Encapsulation. DNA Cell Biol. 2014, 33, 749-774. [CrossRef]

88. Huna, A.; Salmina, K.; Jascenko, E.; Duburs, G.; Inashkina, I.; Erenpreisa, J. Self-Renewal Signalling in Presenescent Tetraploid IMR90 Cells. J. Aging Res. 2011, 2011, 103253. [CrossRef]

89. Niu, N.; Mercado-Uribe, I.; Liu, J. Dedifferentiation into Blastomere-like Cancer Stem Cells via Formation of Polyploid Giant Cancer Cells. Oncogene 2017, 36, 4887-4900. [CrossRef]

90. Liu, J. The Dualistic Origin of Human Tumors. Semin. Cancer Biol. 2018, 53, 1-16. [CrossRef]

91. Lapasset, L.; Milhavet, O.; Prieur, A.; Besnard, E.; Babled, A.; Aït-Hamou, N.; Leschik, J.; Pellestor, F.; Ramirez, J.-M.; De Vos, J.; et al. Rejuvenating Senescent and Centenarian Human Cells by Reprogramming through the Pluripotent State. Genes Dev. 2011, 25, 2248-2253. [CrossRef]

92. Nicaise, A.M.; Wagstaff, L.J.; Willis, C.M.; Paisie, C.; Chandok, H.; Robson, P.; Fossati, V.; Williams, A.; Crocker, S.J. Cellular Senescence in Progenitor Cells Contributes to Diminished Remyelination Potential in Progressive Multiple Sclerosis. Proc. Natl. Acad. Sci. USA 2019, 116, 9030-9039. [CrossRef] [PubMed]

93. Zhu, P.; Zhang, C.; Gao, Y.; Wu, F.; Zhou, Y.; Wu, W.-S. The Transcription Factor Slug Represses P16Ink4a and Regulates Murine Muscle Stem Cell Aging. Nat. Commun. 2019, 10, 2568. [CrossRef] [PubMed]

94. Ohashi, S.; Natsuizaka, M.; Wong, G.S.; Michaylira, C.Z.; Grugan, K.D.; Stairs, D.B.; Kalabis, J.; Vega, M.E.; Kalman, R.A.; Nakagawa, M.; et al. Epidermal Growth Factor Receptor and Mutant P53 Expand an Esophageal Cellular Subpopulation Capable of Epithelial-to-Mesenchymal Transition through ZEB Transcription Factors. Cancer Res. 2010, 70, 4174-4184. [CrossRef] 
95. Morel, A.-P.; Ginestier, C.; Pommier, R.M.; Cabaud, O.; Ruiz, E.; Wicinski, J.; Devouassoux-Shisheboran, M.; Combaret, V.; Finetti, P.; Chassot, C.; et al. A Stemness-Related ZEB1-MSRB3 Axis Governs Cellular Pliancy and Breast Cancer Genome Stability. Nat. Med. 2017, 23, 568-578. [CrossRef]

96. Pommier, R.M.; Sanlaville, A.; Tonon, L.; Kielbassa, J.; Thomas, E.; Ferrari, A.; Sertier, A.S.; Hollande, F.; Martinez, P.; Tissier, A.; et al. Comprehensive Characterization of Claudin-Low Breast Tumors Reflects the Impact of the Cell-of-Origin on Cancer Evolution. Nat. Commun. 2020, 11, 3431. [CrossRef] [PubMed]

97. Visvader, J.E. Cells of Origin in Cancer. Nature 2011, 469, 314-322. [CrossRef]

98. Chen, X.; Pappo, A.; Dyer, M.A. Pediatric Solid Tumor Genomics and Developmental Pliancy. Oncogene 2015, 34, 5207-5215. [CrossRef]

99. Coppé, J.P.; Patil, C.K.; Rodier, F.; Sun, Y.; Muñoz, D.P.; Goldstein, J.; Nelson, P.S.; Desprez, P.Y.; Campisi, J. Senescence-Associated Secretory Phenotypes Reveal Cell-Nonautonomous Functions of Oncogenic RAS and the P53 Tumor Suppressor. PLoS Biol. 2008, 6, e301. [CrossRef]

100. Ohanna, M.; Giuliano, S.; Bonet, C.; Imbert, V.; Hofman, V.; Zangari, J.; Bille, K.; Robert, C.; Bressac-de Paillerets, B.; Hofman, P.; et al. Senescent Cells Develop a PARP-1 and Nuclear Factor-KappaB-Associated Secretome (PNAS). Genes Dev. 2011, 25, 1245-1261. [CrossRef]

101. Coppé, J.-P.; Rodier, F.; Patil, C.K.; Freund, A.; Desprez, P.-Y.; Campisi, J. Tumor Suppressor and Aging Biomarker P16(INK4a) Induces Cellular Senescence without the Associated Inflammatory Secretory Phenotype. J. Biol. Chem. 2011, $286,36396-36403$. [CrossRef]

102. Laberge, R.M.; Sun, Y.; Orjalo, A.V.; Patil, C.K.; Freund, A.; Zhou, L.; Curran, S.C.; Davalos, A.R.; Wilson-Edell, K.A.; Liu, S.; et al. MTOR Regulates the Pro-Tumorigenic Senescence-Associated Secretory Phenotype by Promoting IL1A Translation. Nat. Cell Biol. 2015, 17, 1049-1061. [CrossRef]

103. Wiley, C.D.; Velarde, M.C.; Lecot, P.; Liu, S.; Sarnoski, E.A.; Freund, A.; Shirakawa, K.; Lim, H.W.; Davis, S.S.; Ramanathan, A.; et al. Mitochondrial Dysfunction Induces Senescence with a Distinct Secretory Phenotype. Cell Metab. 2016, $23,303-314$. [CrossRef] [PubMed]

104. Basisty, N.; Kale, A.; Jeon, O.H.; Kuehnemann, C.; Payne, T.; Rao, C.; Holtz, A.; Shah, S.; Sharma, V.; Ferrucci, L.; et al. A Proteomic Atlas of Senescence-Associated Secretomes for Aging Biomarker Development. PLoS Biol. 2020, 18, e3000599. [CrossRef]

105. Glück, S.; Guey, B.; Gulen, M.F.; Wolter, K.; Kang, T.-W.; Schmacke, N.A.; Bridgeman, A.; Rehwinkel, J.; Zender, L.; Ablasser, A. Innate Immune Sensing of Cytosolic Chromatin Fragments through CGAS Promotes Senescence. Nat. Cell Biol. 2017, 19, 1061-1070. [CrossRef]

106. Freund, A.; Patil, C.K.; Campisi, J. P38MAPK Is a Novel DNA Damage Response-Independent Regulator of the SenescenceAssociated Secretory Phenotype. EMBO J. 2011, 30, 1536-1548. [CrossRef]

107. Dou, Z.; Ghosh, K.; Vizioli, M.G.; Zhu, J.; Sen, P.; Wangensteen, K.J.; Simithy, J.; Lan, Y.; Lin, Y.; Zhou, Z.; et al. Cytoplasmic Chromatin Triggers Inflammation in Senescence and Cancer. Nature 2017, 550, 402-406. [CrossRef] [PubMed]

108. Takahashi, A.; Loo, T.M.; Okada, R.; Kamachi, F.; Watanabe, Y.; Wakita, M.; Watanabe, S.; Kawamoto, S.; Miyata, K.; Barber, G.N.; et al. Downregulation of Cytoplasmic DNases Is Implicated in Cytoplasmic DNA Accumulation and SASP in Senescent Cells. Nat. Commun. 2018, 9, 1249. [CrossRef] [PubMed]

109. Yang, H.; Wang, H.; Ren, J.; Chen, Q.; Chen, Z.J. CGAS Is Essential for Cellular Senescence. Proc. Natl. Acad. Sci. USA 2017, 114, E4612-E4620. [CrossRef]

110. Wang, B.; Brandenburg, S.; Hernandez-Segura, A.; van Vliet, T.; Jongbloed, E.M.; Wilting, S.M.; Ohtani, N.; Jager, A.; Demaria, M. Pharmacological CDK4/6 Inhibition Unravels a P53-Induced Secretory Phenotype in Senescent Cells. bioRxiv 2020. [CrossRef]

111. Mosteiro, L.; Pantoja, C.; de Martino, A.; Serrano, M. Senescence Promotes in Vivo Reprogramming through P16 INK4a and IL-6. Aging Cell 2018, 17, e12711. [CrossRef] [PubMed]

112. Ohnishi, K.; Semi, K.; Yamamoto, T.; Shimizu, M.; Tanaka, A.; Mitsunaga, K.; Okita, K.; Osafune, K.; Arioka, Y.; Maeda, T.; et al. Premature Termination of Reprogramming in Vivo Leads to Cancer Development through Altered Epigenetic Regulation. Cell 2014, 156, 663-677. [CrossRef]

113. Iglesias, J.M.; Gumuzio, J.; Martin, A.G. Linking Pluripotency Reprogramming and Cancer. Stem Cells Transl. Med. 2017, 6, 335-339. [CrossRef]

114. Ahn, J.; Xia, T.; Konno, H.; Konno, K.; Ruiz, P.; Barber, G.N. Inflammation-Driven Carcinogenesis Is Mediated through STING. Nat. Commun. 2014, 5, 5166. [CrossRef] [PubMed]

115. Malaquin, N.; Vercamer, C.; Bouali, F.; Martien, S.; Deruy, E.; Wernert, N.; Chwastyniak, M.; Pinet, F.; Abbadie, C.; Pourtier, A. Senescent Fibroblasts Enhance Early Skin Carcinogenic Events via a Paracrine MMP-PAR-1 Axis. PLoS ONE 2013,8 , e63607. [CrossRef] [PubMed]

116. Alimirah, F.; Pulido, T.; Valdovinos, A.; Alptekin, S.; Chang, E.; Jones, E.; Diaz, D.A.; Flores, J.; Velarde, M.C.; Demaria, M.; et al. Cellular Senescence Promotes Skin Carcinogenesis through P38MAPK and P44/42MAPK Signaling. Cancer Res. 2020, 80, 3606-3619. [CrossRef]

117. Jun, J.-I.; Lau, L.F. Cellular Senescence Controls Fibrosis in Wound Healing. Aging (Albany NY) 2010, 2, 627-631. [CrossRef]

118. Kang, T.-W.; Yevsa, T.; Woller, N.; Hoenicke, L.; Wuestefeld, T.; Dauch, D.; Hohmeyer, A.; Gereke, M.; Rudalska, R.; Potapova, A.; et al. Senescence Surveillance of Pre-Malignant Hepatocytes Limits Liver Cancer Development. Nature 2011, 479, 547-551. [CrossRef] 
119. Xue, W.; Zender, L.; Miething, C.; Dickins, R.A.; Hernando, E.; Krizhanovsky, V.; Cordon-Cardo, C.; Lowe, S.W. Senescence and Tumour Clearance Is Triggered by P53 Restoration in Murine Liver Carcinomas. Nature 2007, 445, 656-660. [CrossRef]

120. Gonçalves, S.; Yin, K.; Ito, Y.; Chan, A.; Olan, I.; Gough, S.; Cassidy, L.; Serrao, E.; Smith, S.; Young, A.; et al. COX2 Regulates Senescence Secretome Composition and Senescence Surveillance through PGE2. Cell Rep. 2021, 34, 108860. [CrossRef]

121. Lau, L.; David, G. Pro- and Anti-Tumorigenic Functions of the Senescence-Associated Secretory Phenotype. Expert Opin. Ther. Targets 2019, 23, 1041-1051. [CrossRef]

122. Ortiz-Montero, P.; Londoño-Vallejo, A.; Vernot, J.P. Senescence-Associated IL-6 and IL-8 Cytokines Induce a Self- and CrossReinforced Senescence/Inflammatory Milieu Strengthening Tumorigenic Capabilities in the MCF-7 Breast Cancer Cell Line. Cell Commun. Signal. 2017, 15, 17. [CrossRef]

123. Vernot, J.P. Senescence-Associated Pro-Inflammatory Cytokines and Tumor Cell Plasticity. Front. Mol. Biosci. 2020, 7, 63. [CrossRef]

124. Lujambio, A.; Akkari, L.; Simon, J.; Grace, D.; Tschaharganeh, D.F.; Bolden, J.E.; Zhao, Z.; Thapar, V.; Joyce, J.A.; Krizhanovsky, V.; et al. Non-Cell-Autonomous Tumor Suppression by P53. Cell 2013, 153, 449-460. [CrossRef]

125. Tasdemir, N.; Banito, A.; Roe, J.-S.; Alonso-Curbelo, D.; Camiolo, M.; Tschaharganeh, D.F.; Huang, C.-H.; Aksoy, O.; Bolden, J.E.; Chen, C.-C.; et al. BRD4 Connects Enhancer Remodeling to Senescence Immune Surveillance. Cancer Discov. 2016, 6, 612-629. [CrossRef]

126. Iannello, A.; Thompson, T.W.; Ardolino, M.; Lowe, S.W.; Raulet, D.H. P53-Dependent Chemokine Production by Senescent Tumor Cells Supports NKG2D-Dependent Tumor Elimination by Natural Killer Cells. J. Exp. Med. 2013, 210, 2057-2069. [CrossRef]

127. Krizhanovsky, V.; Yon, M.; Dickins, R.A.; Hearn, S.; Simon, J.; Miething, C.; Yee, H.; Zender, L.; Lowe, S.W. Senescence of Activated Stellate Cells Limits Liver Fibrosis. Cell 2008, 134, 657-667. [CrossRef]

128. Sagiv, A.; Biran, A.; Yon, M.; Simon, J.; Lowe, S.W.; Krizhanovsky, V. Granule Exocytosis Mediates Immune Surveillance of Senescent Cells. Oncogene 2013, 32, 1971-1977. [CrossRef]

129. Sagiv, A.; Burton, D.G.A.; Moshayev, Z.; Vadai, E.; Wensveen, F.; Ben-Dor, S.; Golani, O.; Polic, B.; Krizhanovsky, V. NKG2D Ligands Mediate Immunosurveillance of Senescent Cells. Aging (Albany NY) 2016, 8, 328-344. [CrossRef]

130. Muñoz, D.P.; Yannone, S.M.; Daemen, A.; Sun, Y.; Vakar-Lopez, F.; Kawahara, M.; Freund, A.M.; Rodier, F.; Wu, J.D.; Desprez P.-Y.; et al. Targetable Mechanisms Driving Immunoevasion of Persistent Senescent Cells Link Chemotherapy-Resistant Cancer to Aging. JCI Insight 2019, 4, e124716. [CrossRef]

131. Pereira, B.I.; Devine, O.P.; Vukmanovic-Stejic, M.; Chambers, E.S.; Subramanian, P.; Patel, N.; Virasami, A.; Sebire, N.J.; Kinsler, V.; Valdovinos, A.; et al. Senescent Cells Evade Immune Clearance via HLA-E-Mediated NK and CD8+ T Cell Inhibition. Nat. Commun. 2019, 10, 2387. [CrossRef] [PubMed]

132. Miranda, A.; Hamilton, P.T.; Zhang, A.W.; Pattnaik, S.; Becht, E.; Mezheyeuski, A.; Bruun, J.; Micke, P.; de Reynies, A.; Nelson, B.H. Cancer Stemness, Intratumoral Heterogeneity, and Immune Response across Cancers. Proc. Natl. Acad. Sci. USA 2019, 116, 9020-9029. [CrossRef] [PubMed]

133. Paczulla, A.M.; Rothfelder, K.; Raffel, S.; Konantz, M.; Steinbacher, J.; Wang, H.; Tandler, C.; Mbarga, M.; Schaefer, T.; Falcone, M.; et al. Absence of $\{$ NKG\}2D Ligands Defines Leukaemia Stem Cells and Mediates Their Immune Evasion. Nature 2019, 572, 254-259. [CrossRef] [PubMed]

134. Agudo, J.; Park, E.S.; Rose, S.A.; Alibo, E.; Sweeney, R.; Dhainaut, M.; Kobayashi, K.S.; Sachidanandam, R.; Baccarini, A.; Merad, M.; et al. Quiescent Tissue Stem Cells Evade Immune Surveillance. Immunity 2018, 48, 271-285.e5. [CrossRef] [PubMed]

135. Koebel, C.M.; Vermi, W.; Swann, J.B.; Zerafa, N.; Rodig, S.J.; Old, L.J.; Smyth, M.J.; Schreiber, R.D. Adaptive Immunity Maintains Occult Cancer in an Equilibrium State. Nature 2007, 450, 903-907. [CrossRef] [PubMed]

136. Malladi, S.; Macalinao, D.G.; Jin, X.; He, L.; Basnet, H.; Zou, Y.; de Stanchina, E.; Massagué, J. Metastatic Latency and Immune Evasion through Autocrine Inhibition of WNT. Cell 2016, 165, 45-60. [CrossRef] [PubMed]

137. Burr, M.L.; Sparbier, C.E.; Chan, K.L.; Chan, Y.-C.; Kersbergen, A.; Lam, E.Y.N.; Azidis-Yates, E.; Vassiliadis, D.; Bell, C.C.; Gilan, O.; et al. An Evolutionarily Conserved Function of Polycomb Silences the MHC Class I Antigen Presentation Pathway and Enables Immune Evasion in Cancer. Cancer Cell 2019, 36, 385-401.e8. [CrossRef] [PubMed]

138. Laughney, A.M.; Hu, J.; Campbell, N.R.; Bakhoum, S.F.; Setty, M.; Lavallée, V.-P.; Xie, Y.; Masilionis, I.; Carr, A.J.; Kottapalli, S.; et al. Regenerative Lineages and Immune-Mediated Pruning in Lung Cancer Metastasis. Nat. Med. 2020, 26, 259-269. [CrossRef]

139. Pommier, A.; Anaparthy, N.; Memos, N.; Kelley, Z.L.; Gouronnec, A.; Yan, R.; Auffray, C.; Albrengues, J.; Egeblad, M.; IacobuzioDonahue, C.A.; et al. Unresolved Endoplasmic Reticulum Stress Engenders Immune-Resistant, Latent Pancreatic Cancer Metastases. Science 2018, 360, 6394. [CrossRef]

140. Terry, S.; Savagner, P.; Ortiz-Cuaran, S.; Mahjoubi, L.; Saintigny, P.; Thiery, J.-P.; Chouaib, S. New Insights into the Role of EMT in Tumor Immune Escape. Mol. Oncol. 2017, 11, 824-846. [CrossRef]

141. Knutson, K.L.; Lu, H.; Stone, B.; Reiman, J.M.; Behrens, M.D.; Prosperi, C.M.; Gad, E.A.; Smorlesi, A.; Disis, M.L. Immunoediting of Cancers May Lead to Epithelial to Mesenchymal Transition. J. Immunol. 2006, 177, 1526-1533. [CrossRef]

142. Eggert, T.; Wolter, K.; Ji, J.; Ma, C.; Yevsa, T.; Klotz, S.; Medina-Echeverz, J.; Longerich, T.; Forgues, M.; Reisinger, F.; et al. Distinct Functions of Senescence-Associated Immune Responses in Liver Tumor Surveillance and Tumor Progression. Cancer Cell 2016, 30, 533-547. [CrossRef] 
143. Hoechst, B.; Voigtlaender, T.; Ormandy, L.; Gamrekelashvili, J.; Zhao, F.; Wedemeyer, H.; Lehner, F.; Manns, M.P.; Greten, T.F.; Korangy, F. Myeloid Derived Suppressor Cells Inhibit Natural Killer Cells in Patients with Hepatocellular Carcinoma via the NKp30 Receptor. Hepatology 2009, 50, 799-807. [CrossRef]

144. Elmore, L.W.; Di, X.; Dumur, C.; Holt, S.E.; Gewirtz, D.A. Evasion of a Single-Step, Chemotherapy-Induced Senescence in Breast Cancer Cells: Implications for Treatment Response. Clin. Cancer Res. 2005, 11, 2637-2643. [CrossRef]

145. Roberson, R.S.; Kussick, S.J.; Vallieres, E.; Chen, S.-Y.J.; Wu, D.Y. Escape from Therapy-Induced Accelerated Cellular Senescence in P53-Null Lung Cancer Cells and in Human Lung Cancers. Cancer Res. 2005, 65, 2795-2803. [CrossRef] [PubMed]

146. Walter, P.; Pusel, J.; Rousselot, P. Multinucleated Giant Cell Tumor of the Thyroid: An Unusual Anaplastic Carcinoma (Author's Transl). Pathol. Res. Pract. 1980, 167, 402-409. [CrossRef]

147. Douglas-Jones, A.G.; Barr, W.T. Breast Carcinoma with Tumor Giant Cells. Report of a Case with Fine Needle Aspiration Cytology. Acta. Cytol. 1989, 33, 109-114. [PubMed]

148. Jones, M.A.; Young, R.H.; Scully, R.E. Endometrial Adenocarcinoma with a Component of Giant Cell Carcinoma. Int. J. Gynecol. Pathol. 1991, 10, 260-270. [CrossRef] [PubMed]

149. Zack, T.I.; Schumacher, S.E.; Carter, S.L.; Cherniack, A.D.; Saksena, G.; Tabak, B.; Lawrence, M.S.; Zhsng, C.-Z.; Wala, J.; Mermel, C.H.; et al. Pan-Cancer Patterns of Somatic Copy Number Alteration. Nat. Genet. 2013, 45, 1134-1140. [CrossRef] [PubMed]

150. Bielski, C.M.; Zehir, A.; Penson, A.V.; Donoghue, M.T.A.; Chatila, W.; Armenia, J.; Chang, M.T.; Schram, A.M.; Jonsson, P.; Bandlamudi, C.; et al. Genome Doubling Shapes the Evolution and Prognosis of Advanced Cancers. Nat. Genet. 2018, 50, 1189-1195. [CrossRef]

151. Zhang, S.; Mercado-Uribe, I.; Xing, Z.; Sun, B.; Kuang, J.; Liu, J. Generation of Cancer Stem-like Cells through the Formation of Polyploid Giant Cancer Cells. Oncogene 2014, 33, 116-128. [CrossRef]

152. Mosieniak, G.; Sliwinska, M.A.; Alster, O.; Strzeszewska, A.; Sunderland, P.; Piechota, M.; Was, H.; Sikora, E. Polyploidy Formation in Doxorubicin-Treated Cancer Cells Can Favor Escape from Senescence. Neoplasia 2015, 17, 882-893. [CrossRef]

153. Rohnalter, V.; Roth, K.; Finkernagel, F.; Adhikary, T.; Obert, J.; Dorzweiler, K.; Bensberg, M.; Müller-Brüsselbach, S.; Müller, R. A Multi-Stage Process Including Transient Polyploidization and EMT Precedes the Emergence of Chemoresistent Ovarian Carcinoma Cells with a Dedifferentiated and pro-Inflammatory Secretory Phenotype. Oncotarget 2015, 6, 40005-40025. [CrossRef] [PubMed]

154. Puig, P.-E.; Guilly, M.-N.; Bouchot, A.; Droin, N.; Cathelin, D.; Bouyer, F.; Favier, L.; Ghiringhelli, F.; Kroemer, G.; Solary, E.; et al. Tumor Cells Can Escape DNA-Damaging Cisplatin through DNA Endoreduplication and Reversible Polyploidy. Cell Biol. Int. 2008, 32, 1031-1043. [CrossRef]

155. Wang, Q.; Wu, P.C.; Dong, D.Z.; Ivanova, I.; Chu, E.; Zeliadt, S.; Vesselle, H.; Wu, D.Y. Polyploidy Road to Therapy-Induced Cellular Senescence and Escape. Int. J. Cancer 2013, 132, 1505-1515. [CrossRef]

156. Fei, F.; Zhang, D.; Yang, Z.; Wang, S.; Wang, X.; Wu, Z.; Wu, Q.; Zhang, S. The Number of Polyploid Giant Cancer Cells and Epithelial-Mesenchymal Transition-Related Proteins Are Associated with Invasion and Metastasis in Human Breast Cancer. J. Exp. Clin. Cancer Res. 2015, 34, 158. [CrossRef]

157. Salmina, K.; Jankevics, E.; Huna, A.; Perminov, D.; Radovica, I.; Klymenko, T.; Ivanov, A.; Jascenko, E.; Scherthan, H.; Cragg, M.; et al. Up-Regulation of the Embryonic Self-Renewal Network through Reversible Polyploidy in Irradiated P53-Mutant Tumour. Exp. Cell Res. 2010, 316, 2099-2112. [CrossRef] [PubMed]

158. Lagadec, C.; Vlashi, E.; Della Donna, L.; Dekmezian, C.; Pajonk, F. Radiation-Induced Reprogramming of Breast Cancer Cells. Stem Cells 2012, 30, 833-844. [CrossRef] [PubMed]

159. Weihua, Z.; Lin, Q.; Ramoth, A.J.; Fan, D.; Fidler, I.J. Formation of Solid Tumors by a Single Multinucleated Cancer Cell. Cancer 2011, 117, 4092-4099. [CrossRef]

160. Milanovic, M.; Fan, D.N.Y.; Belenki, D.; Däbritz, J.H.M.; Zhao, Z.; Yu, Y.; Dörr, J.R.; Dimitrova, L.; Lenze, D.; Monteiro Barbosa, I.A.; et al. Senescence-Associated Reprogramming Promotes Cancer Stemness. Nature 2018, 553, 96-100. [CrossRef]

161. Dewhurst, S.M.; McGranahan, N.; Burrell, R.A.; Rowan, A.J.; Grönroos, E.; Endesfelder, D.; Joshi, T.; Mouradov, D.; Gibbs, P.; Ward, R.L.; et al. Tolerance of Whole-Genome Doubling Propagates Chromosomal Instability and Accelerates Cancer Genome Evolution. Cancer Discov. 2014, 4, 175-185. [CrossRef]

162. Salmina, K.; Bojko, A.; Inashkina, I.; Staniak, K.; Dudkowska, M.; Podlesniy, P.; Rumnieks, F.; Vainshelbaum, N.M.; Pjanova, D.; Sikora, E.; et al. "Mitotic Slippage" and Extranuclear DNA in Cancer Chemoresistance: A Focus on Telomeres. Int. J. Mol. Sci. 2020, 21, 2779. [CrossRef]

163. Achuthan, S.; Santhoshkumar, T.R.; Prabhakar, J.; Nair, S.A.; Pillai, M.R. Drug-Induced Senescence Generates Chemoresistant Stemlike Cells with Low Reactive Oxygen Species. J. Biol. Chem. 2011, 286, 37813-37829. [CrossRef]

164. Ge, J.Y.; Shu, S.; Kwon, M.; Jovanović, B.; Murphy, K.; Gulvady, A.; Fassl, A.; Trinh, A.; Kuang, Y.; Heavey, G.A.; et al. Acquired Resistance to Combined BET and CDK4/6 Inhibition in Triple-Negative Breast Cancer. Nat. Commun. 2020, 11, 2350. [CrossRef] [PubMed]

165. Duy, C.; Li, M.; Teater, M.; Meydan, C.; Garrett-Bakelman, F.E.; Lee, T.C.; Chin, C.R.; Durmaz, C.; Kawabata, K.C.; Dhimolea, E.; et al. Chemotherapy Induces Senescence-like Resilient Cells Capable of Initiating AML Recurrence. Cancer Discov. 2021, 11, 1542-1561. [CrossRef]

166. Iliopoulos, D.; Hirsch, H.A.; Struhl, K. An Epigenetic Switch Involving NF-KappaB, Lin28, Let-7 MicroRNA, and IL6 Links Inflammation to Cell Transformation. Cell 2009, 139, 693-706. [CrossRef] 
167. Iliopoulos, D.; Hirsch, H.A.; Wang, G.; Struhl, K. Inducible Formation of Breast Cancer Stem Cells and Their Dynamic Equilibrium with Non-Stem Cancer Cells via IL6 Secretion. Proc. Natl. Acad. Sci. USA 2011, 108, 1397-1402. [CrossRef] [PubMed]

168. Mitra, A.; Yan, J.; Xia, X.; Zhou, S.; Chen, J.; Mishra, L.; Li, S. IL6-Mediated Inflammatory Loop Reprograms Normal to EpithelialMesenchymal Transition+ Metastatic Cancer Stem Cells in Preneoplastic Liver of Transforming Growth Factor Beta-Deficient B2-Spectrin+/- Mice. Hepatology 2017, 65, 1222-1236. [CrossRef] [PubMed]

169. Cruickshanks, H.A.; McBryan, T.; Nelson, D.M.; Vanderkraats, N.D.; Shah, P.P.; van Tuyn, J.; Singh Rai, T.; Brock, C.; Donahue, G.; Dunican, D.S.; et al. Senescent Cells Harbour Features of the Cancer Epigenome. Nat. Cell Biol. 2013, 15, 1495-1506. [CrossRef]

170. Canino, C.; Mori, F.; Cambria, A.; Diamantini, A.; Germoni, S.; Alessandrini, G.; Borsellino, G.; Galati, R.; Battistini, L.; Blandino, R.; et al. SASP Mediates Chemoresistance and Tumor-Initiating-Activity of Mesothelioma. Oncogene 2012, 31, $3148-3163$. [CrossRef] [PubMed]

171. Cahu, J.; Bustany, S.; Sola, B. Senescence-Associated Secretory Phenotype Favors the Emergence of Cancer Stem-like Cells. Cell Death Dis. 2012, 3, e446. [CrossRef]

172. Mackenzie, K.J.; Carroll, P.; Martin, C.-A.; Murina, O.; Fluteau, A.; Simpson, D.J.; Olova, N.; Sutcliffe, H.; Rainger, J.K.; Leitch, A.; et al. CGAS Surveillance of Micronuclei Links Genome Instability to Innate Immunity. Nature 2017, 548, 461-465. [CrossRef] [PubMed]

173. Demaria, M.; O’Leary, M.N.; Chang, J.; Shao, L.; Liu, S.; Alimirah, F.; Koenig, K.; Le, C.; Mitin, N.; Deal, A.M.; et al. Cellular Senescence Promotes Adverse Effects of Chemotherapy and Cancer Relapse. Cancer Discov. 2017, 7, 165-176. [CrossRef] [PubMed]

174. Kim, Y.H.; Choi, Y.W.; Lee, J.; Soh, E.Y.; Kim, J.-H.; Park, T.J. Senescent Tumor Cells Lead the Collective Invasion in Thyroid Cancer. Nat. Commun. 2017, 8, 15208. [CrossRef] [PubMed]

175. Bakhoum, S.F.; Ngo, B.; Laughney, A.M.; Cavallo, J.-A.; Murphy, C.J.; Ly, P.; Shah, P.; Sriram, R.K.; Watkins, T.B.K.; Taunk, N.K.; et al. Chromosomal Instability Drives Metastasis through a Cytosolic DNA Response. Nature 2018, 553, 467-472. [CrossRef]

176. Braumüller, H.; Wieder, T.; Brenner, E.; Aßmann, S.; Hahn, M.; Alkhaled, M.; Schilbach, K.; Essmann, F.; Kneilling, M.; Griessinger, C.; et al. T-Helper-1-Cell Cytokines Drive Cancer into Senescence. Nature 2013, 494, 361-365. [CrossRef]

177. Sarkisian, C.J.; Keister, B.A.; Stairs, D.B.; Boxer, R.B.; Moody, S.E.; Chodosh, L.A. Dose-Dependent Oncogene-Induced Senescence in Vivo and Its Evasion during Mammary Tumorigenesis. Nat. Cell Biol. 2007, 9, 493-505. [CrossRef] [PubMed]

178. Roninson, I.B.; Broude, E.V.; Chang, B.-D. If Not Apoptosis, Then What? Treatment-Induced Senescence and Mitotic Catastrophe in Tumor Cells. Drug Resist. Updates 2001, 4, 303-313. [CrossRef]

179. Soriani, A.; Zingoni, A.; Cerboni, C.; Iannitto, M.L.; Ricciardi, M.R.; Di Gialleonardo, V.; Cippitelli, M.; Fionda, C.; Petrucci, M.T.; Guarini, A.; et al. ATM-ATR-Dependent up-Regulation of DNAM-1 and NKG2D Ligands on Multiple Myeloma Cells by Therapeutic Agents Results in Enhanced NK-Cell Susceptibility and Is Associated with a Senescent Phenotype. Blood 2009, 113, 3503-3511. [CrossRef] [PubMed]

180. Antonangeli, F.; Soriani, A.; Ricci, B.; Ponzetta, A.; Benigni, G.; Morrone, S.; Bernardini, G.; Santoni, A. Natural Killer Cell Recognition of in Vivo Drug-Induced Senescent Multiple Myeloma Cells. Oncoimmunology 2016, 5, e1218105. [CrossRef]

181. Nguyen, H.Q.; To, N.H.; Zadigue, P.; Kerbrat, S.; De La Taille, A.; Le Gouvello, S.; Belkacemi, Y. Ionizing Radiation-Induced Cellular Senescence Promotes Tissue Fibrosis after Radiotherapy. A Review. Crit. Rev. Oncol. Hematol. 2018, 129, 13-26. [CrossRef]

182. Chen, J.; Li, Y.; Yu, T.S.; McKay, R.M.; Burns, D.K.; Kernie, S.G.; Parada, L.F. A Restricted Cell Population Propagates Glioblastoma Growth after Chemotherapy. Nature 2012, 488, 522-526. [CrossRef] [PubMed]

183. Kobayashi, S.; Yamada-Okabe, H.; Suzuki, M.; Natori, O.; Kato, A.; Matsubara, K.; Jau Chen, Y.; Yamazaki, M.; Funahashi, S.; Yoshida, K.; et al. LGR5-Positive Colon Cancer Stem Cells Interconvert with Drug-Resistant LGR5-Negative Cells and Are Capable of Tumor Reconstitution. Stem Cells 2012, 30, 2631-2644. [CrossRef] [PubMed]

184. Essers, M.A.G.; Offner, S.; Blanco-Bose, W.E.; Waibler, Z.; Kalinke, U.; Duchosal, M.A.; Trumpp, A. IFNalpha Activates Dormant Haematopoietic Stem Cells in Vivo. Nature 2009, 458, 904-908. [CrossRef]

185. Kreso, A.; O’Brien, C.A.; van Galen, P.; Gan, O.I.; Notta, F.; Brown, A.M.K.; Ng, K.; Ma, J.; Wienholds, E.; Dunant, C.; et al. Variable Clonal Repopulation Dynamics Influence Chemotherapy Response in Colorectal Cancer. Science 2013, 339, 543-548. [CrossRef]

186. Chockley, P.J.; Chen, J.; Chen, G.; Beer, D.G.; Standiford, T.J.; Keshamouni, V.G. Epithelial-Mesenchymal Transition Leads to \{NK\} Cell-Mediated Metastasis-Specific Immunosurveillance in Lung Cancer. J. Clin. Investig. 2018, 128, 1384-1396. [CrossRef] [PubMed]

187. Su, S.; Liu, Q.; Chen, J.; Chen, J.; Chen, F.; He, C.; Huang, D.; Wu, W.; Lin, L.; Huang, W.; et al. A Positive Feedback Loop between Mesenchymal-like Cancer Cells and Macrophages Is Essential to Breast Cancer Metastasis. Cancer Cell 2014, 25, 605-620. [CrossRef] [PubMed]

188. Ouzounova, M.; Lee, E.; Piranlioglu, R.; El Andaloussi, A.; Kolhe, R.; Demirci, M.F.; Marasco, D.; Asm, I.; Chadli, A.; Hassan, K.A.; et al. Monocytic and Granulocytic Myeloid Derived Suppressor Cells Differentially Regulate Spatiotemporal Tumour Plasticity during Metastatic Cascade. Nat. Commun. 2017, 8, 14979. [CrossRef] [PubMed]

189. Perkins, D.W.; Haider, S.; Robertson, D.; Buus, R.; O’Leary, L.; Isacke, C.M. Therapy-Induced Senescence in Normal Tissue Promotes Breast Cancer Metastasis. bioRxiv 2020. [CrossRef]

190. Coppe, J.P.; Kauser, K.; Campisi, J.; Beauséjour, C.M. Secretion of Vascular Endothelial Growth Factor by Primary Human Fibroblasts at Senescence. J. Biol. Chem. 2006, 281, 29568-29574. [CrossRef] 